(6) - (6ثث رقم

\title{
التحليل المعرفي والجمالي لظاهرة عري الأقدام في الاعمال التثكيلية ق قديما وحديثا
}

\author{
أويسـس محسمود سناجلة \\ الرتبة مدرس (ب) \\ جامعة البلقاء التطبيقية \\ كلية اربد الجامعية \\ الأردن
}

\section{ألملخص بالعربي}

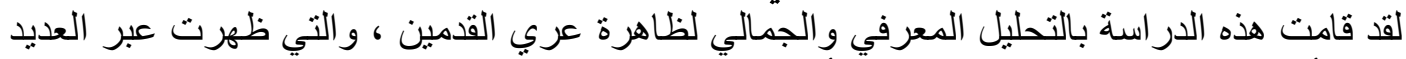

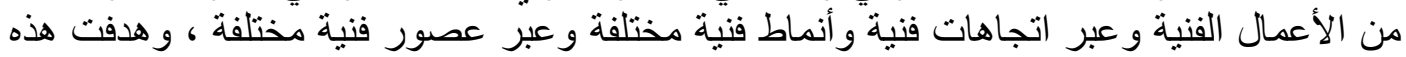

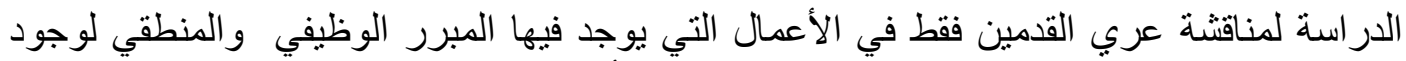

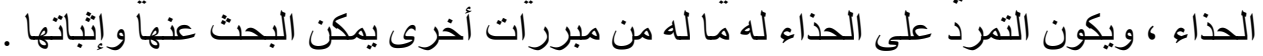

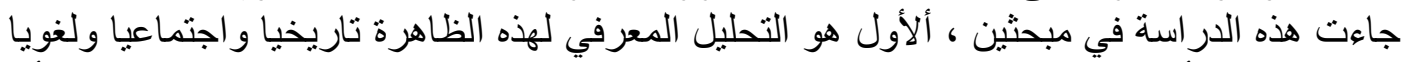

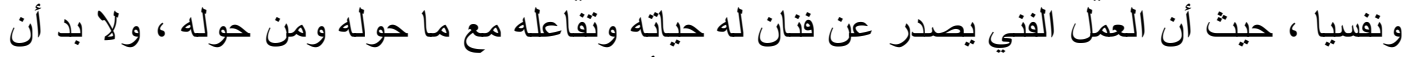

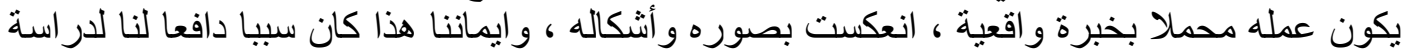

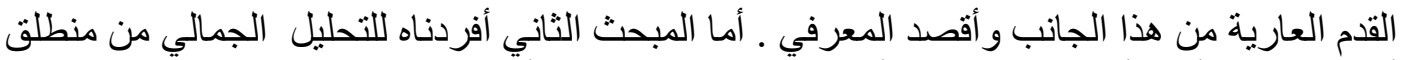

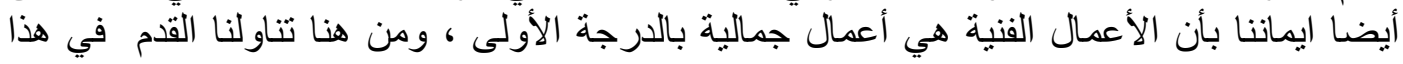


المبحث شكليا ولونيا ورمزيا لنعرف بعض الاجابات على تساؤلنا عن سبب هذا التمظهر للأقدام

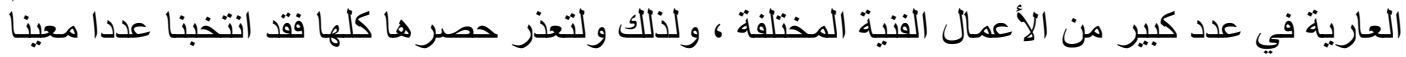

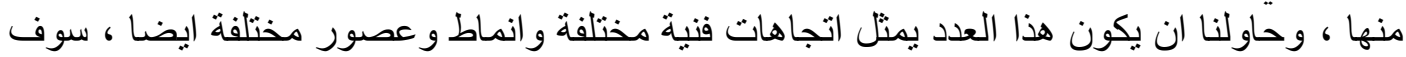

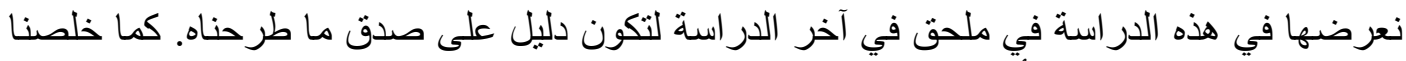

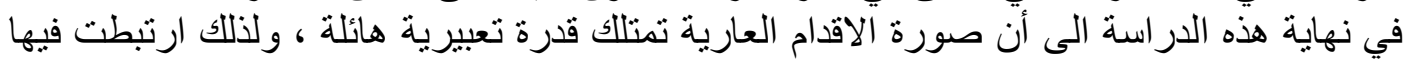

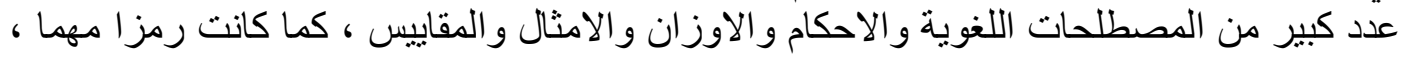

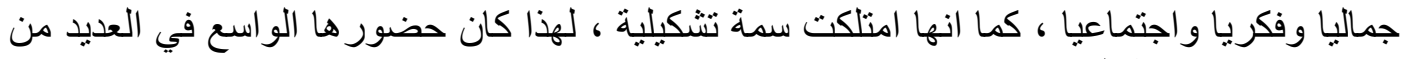

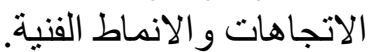

\section{Abstract}

this study analyzed the cognitive and aesthetic phenomenon nudity feet, which appeared across many artworks of art and through the artistic trends of different art styles and across different artistic eras, this study aimed to discuss nudity feet only in the works where there is a rationale of career for the existence of the shoe, and a rebellion against boot has other justifications that can be researched and substantiated.

This study came in two sections, the first is the analysis of knowledge of this phenomenon historically, socially and linguistically, psychologically, where the artwork comes from the artist has his life and his interaction with what and those around him, and his artwork must be done blaming realistic experience, reflected in his forms, and this our belief was the reason a motivation for us to study the bare foot on this side I mean side of knowledge. The second section was analysis aesthetic also came from our belief that works of art are acts of aesthetic primarily, hence we approached the foot in this section from the side of shape color and symbol to know some answers to our inquiries about the reason for this appearance of bare feet in a large number of different works of art, since we can not count all, but we have elected a number of them, we will show them in the latest study to be proof of the sincerity of what we put forward. As we concluded at the end of this study that the image of bare foot has an enormous expressive ability, and therefore their associated large number of linguistic terms and conditions and weights and sayings and standards, as it was an 
important symbol, aesthetically, intellectually and socially, as it possessed figuration features, for this was a widespread presence in several from technical trends and patterns across different eras .

\section{الفصل الأول}

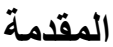

مع أن نقد الفن أو البحث فيه فلسفيا ـ كون الفن ظاهرة لا بد من فهمها- قد لقي الكثير من المقاومة

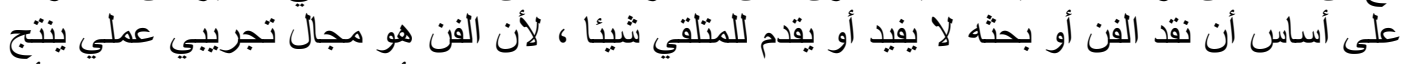

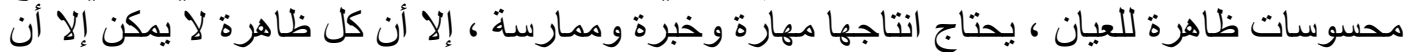

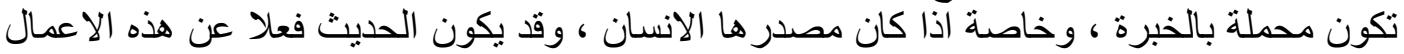

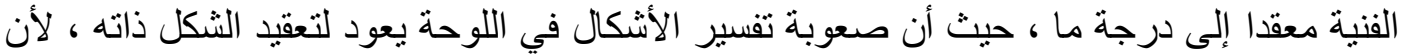

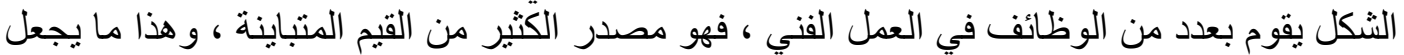

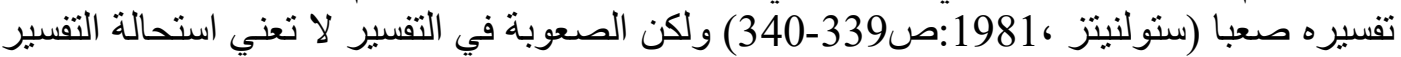

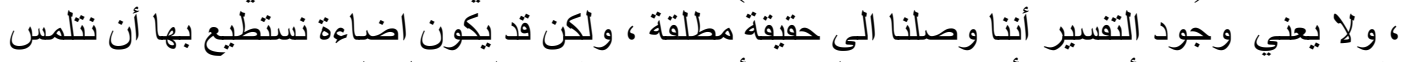

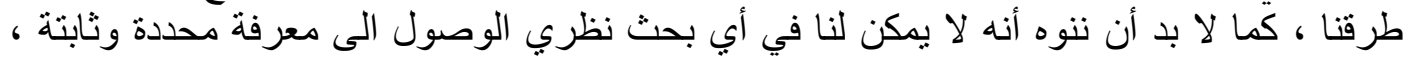

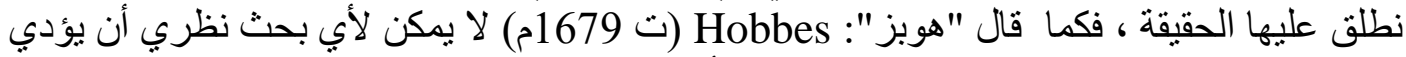

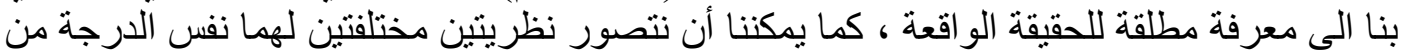

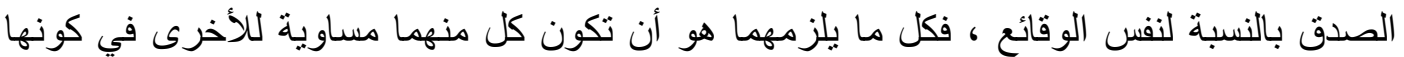

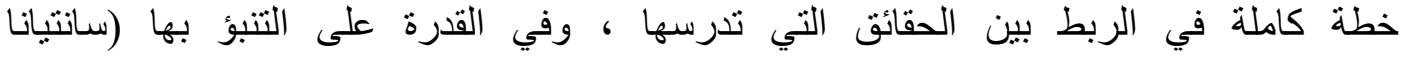
. (199:2001، إن الثكل الجمالي في العمل الفني لله خصوصية تتعلق بالعمل الفني الذي يشكل تعبيرا أو سجلا

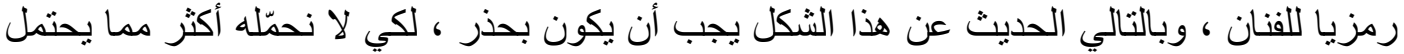

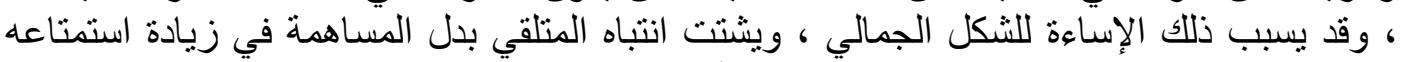

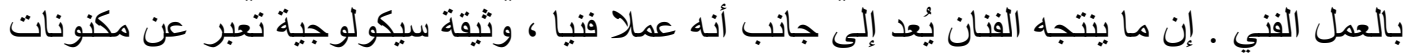

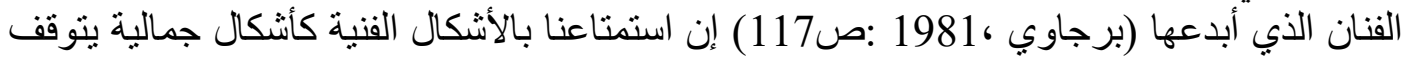

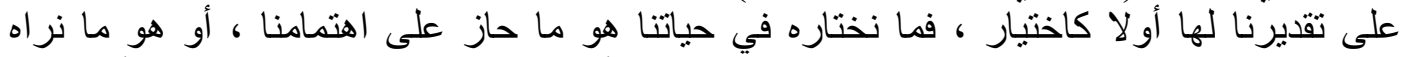

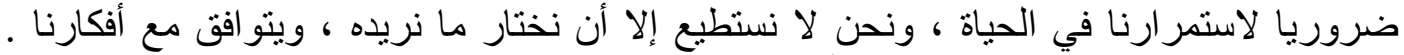

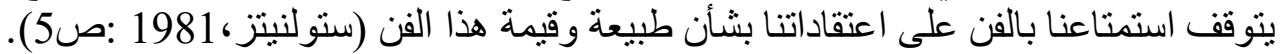

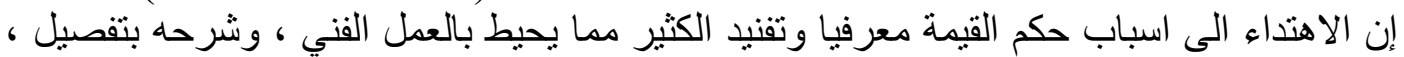

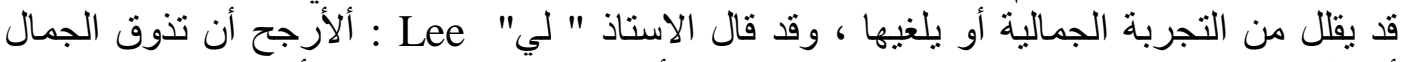

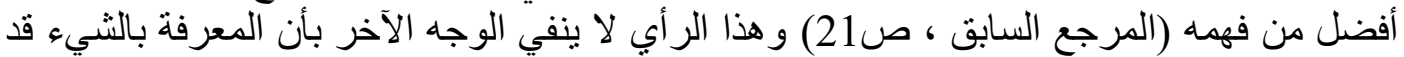

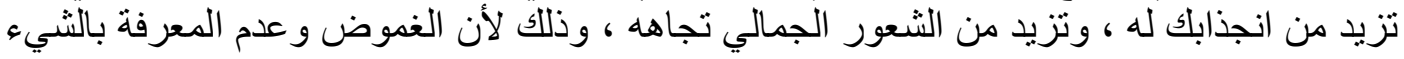




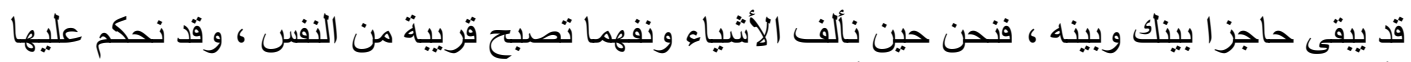

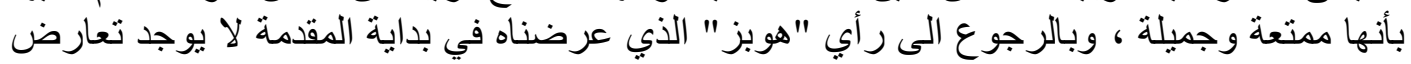

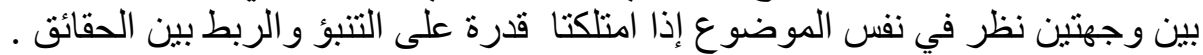

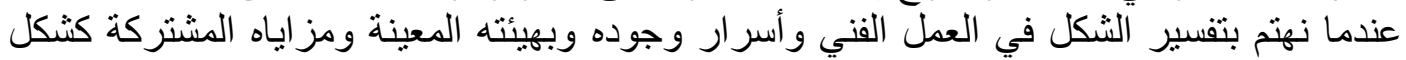

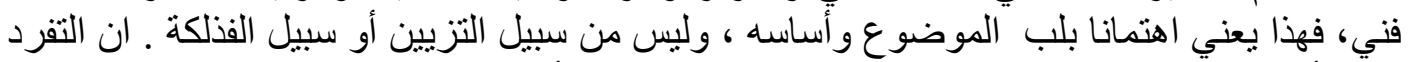

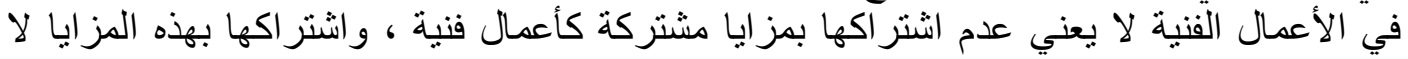

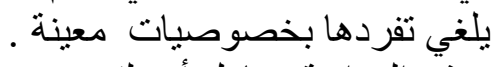

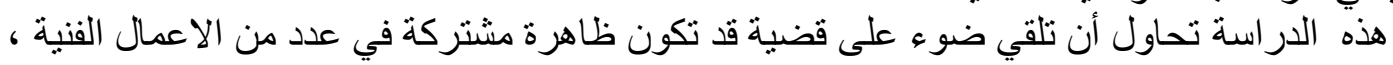

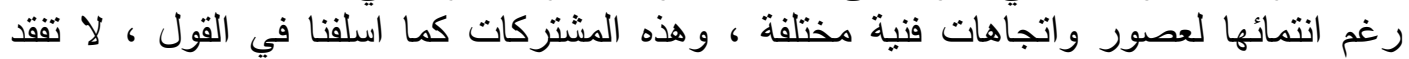

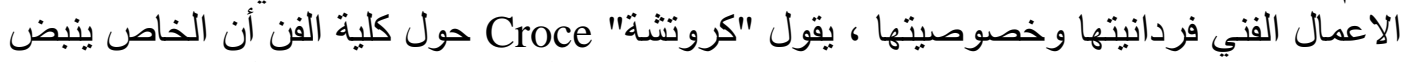

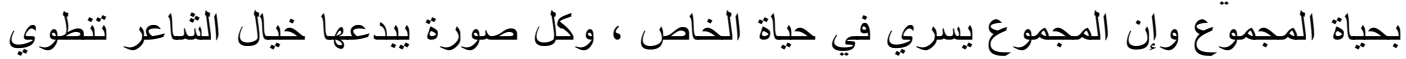

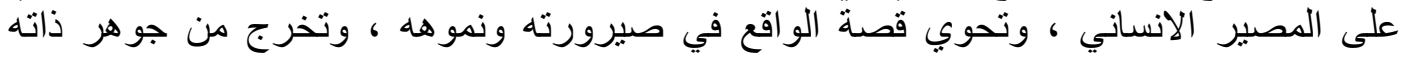

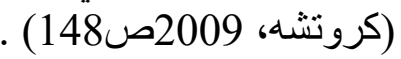

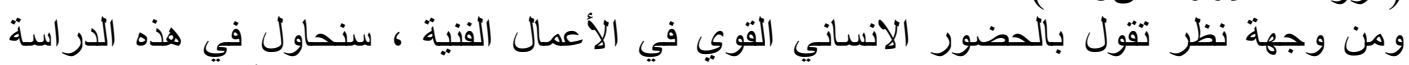

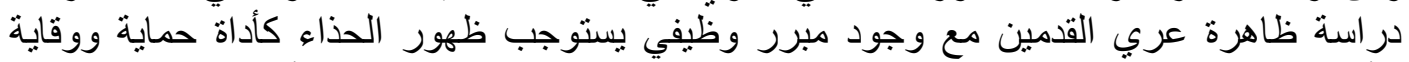

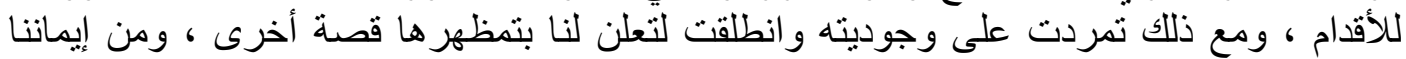

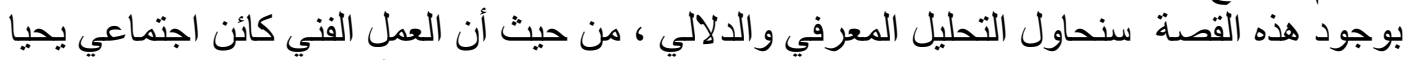

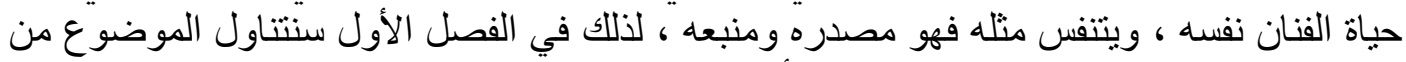

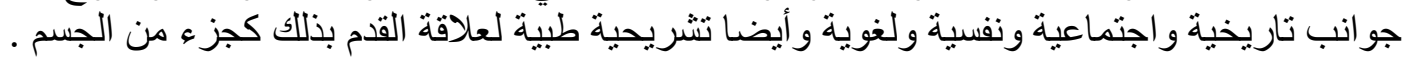

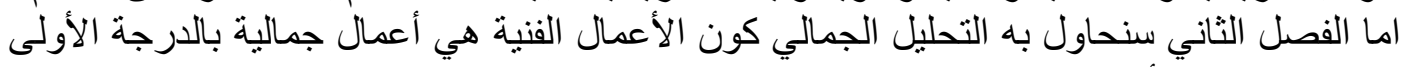
تحكمها عناصر وُ أسس فنية جمالية .

\section{مشكلة البحث}

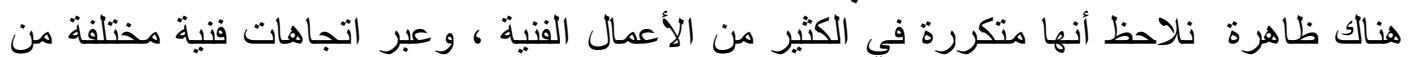

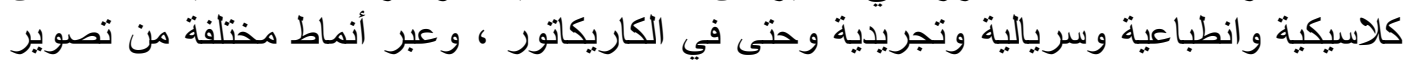

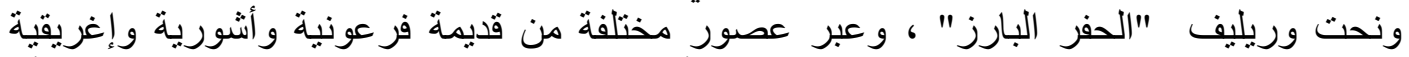

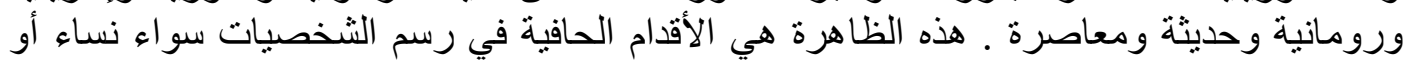

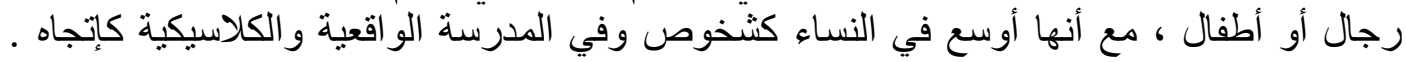

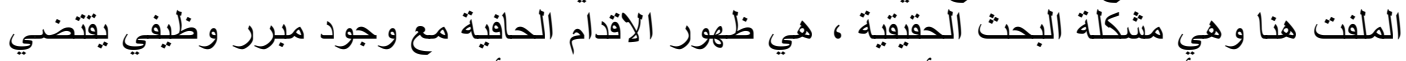

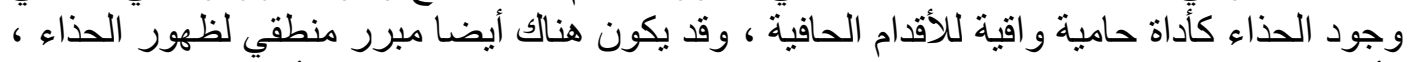

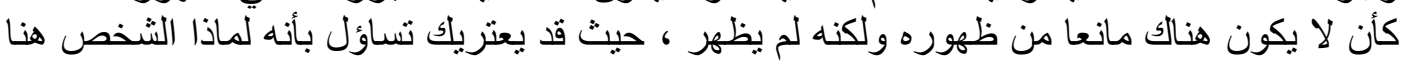

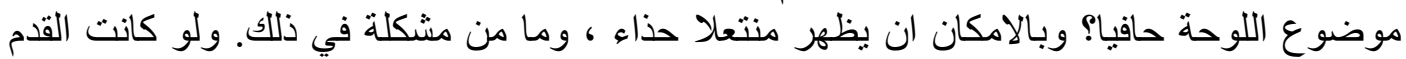

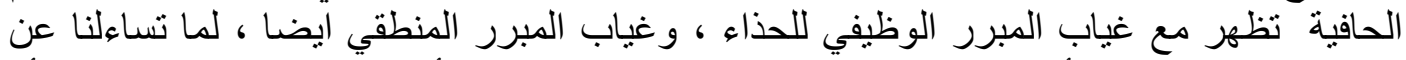

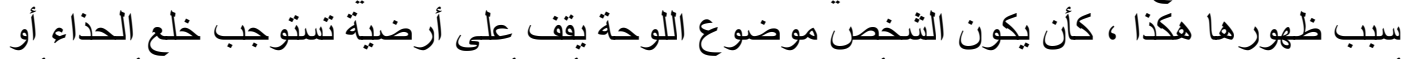
أن يكون عاريا ، فمن غير المنطقي أن ينتعل حذاء فقط ، أو كأن يكون على شاطئ ألى بحر أو في أي أي 


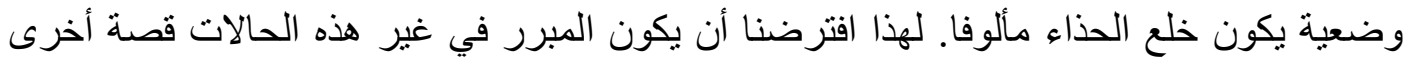

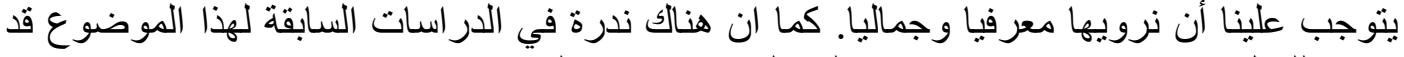

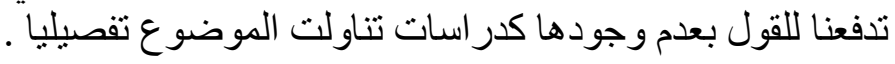

أهمية الدراسة أهية

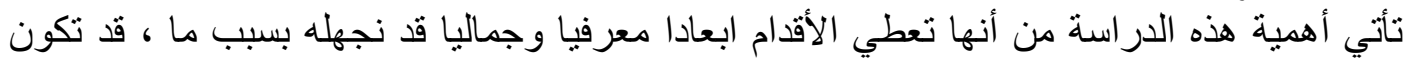

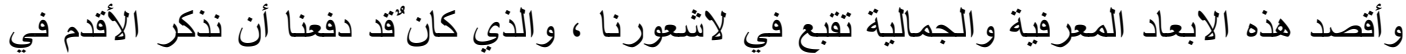

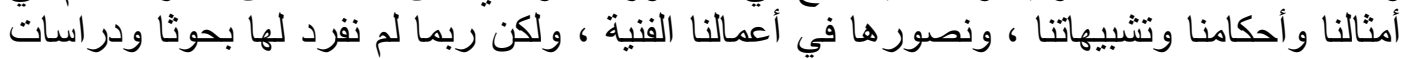

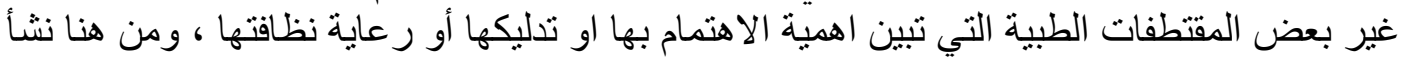

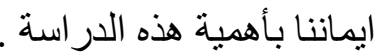

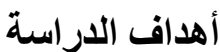

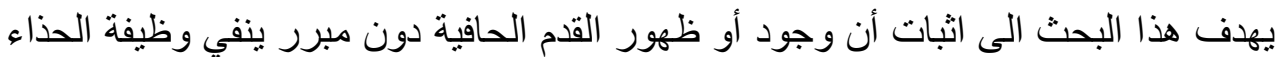

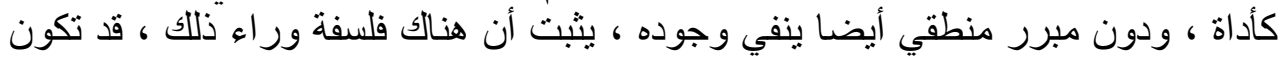

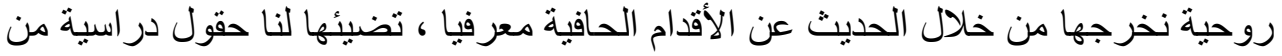

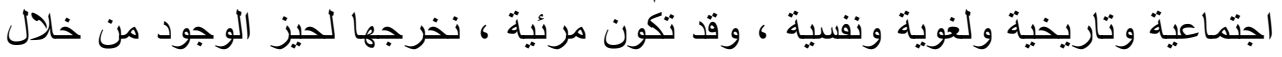

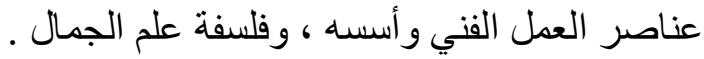

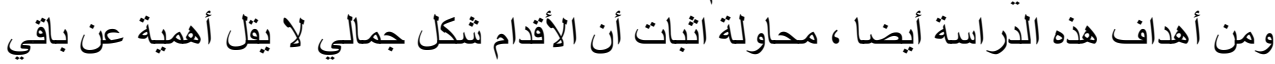
الاعضاء في الجسد ، بل يزيد عن ذلك ، فهي اتزان الننا وشكل هينتئا.

\section{منهج البحث} هذه الدر اسة هي در اسة وصفية تحليلية معرفيا وجماليا .

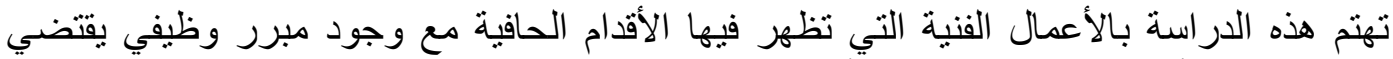

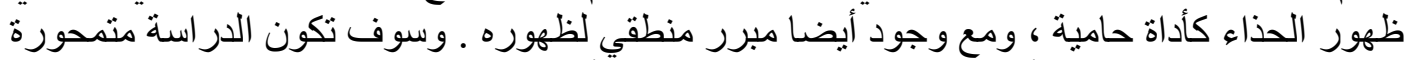

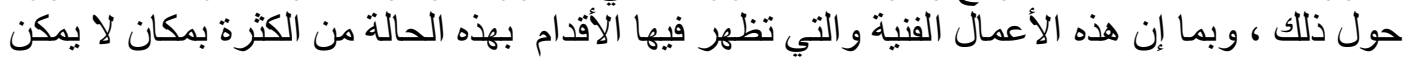

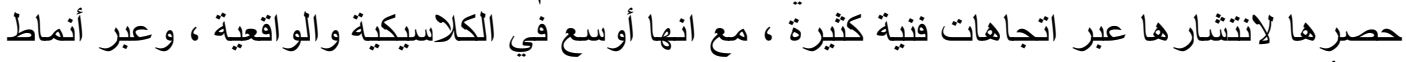

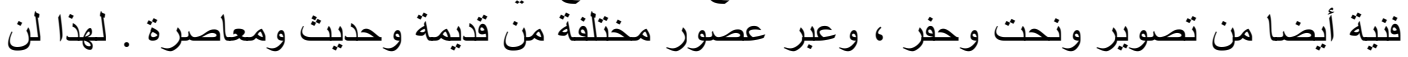

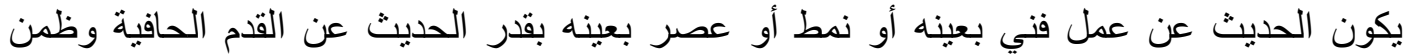

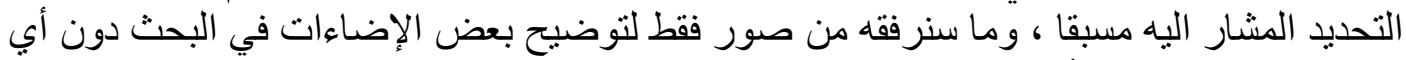

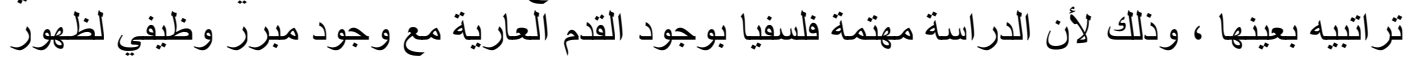

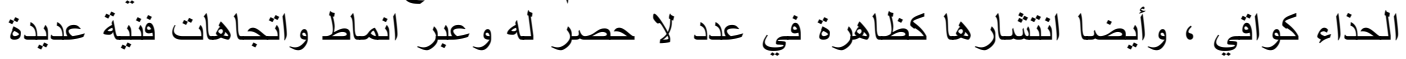

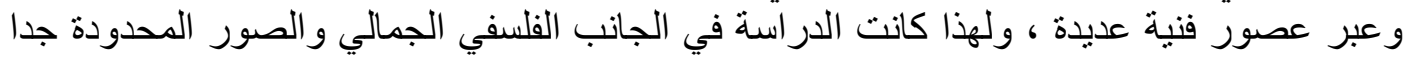
كانت للإضـاءات فقط ، لهذا لم نر اعي تر اتبية معينة . 


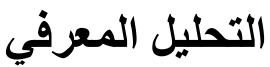

أهمية الشكل المرئي معرفيا

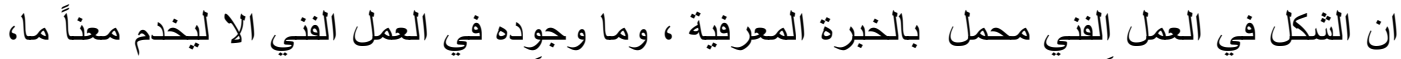

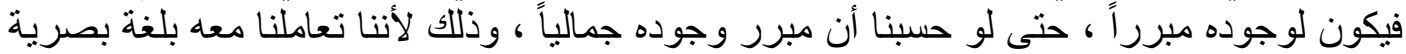

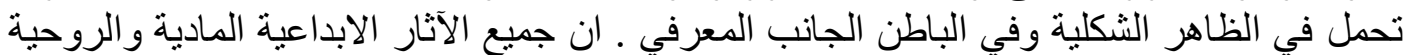

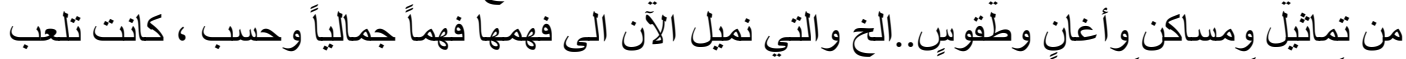

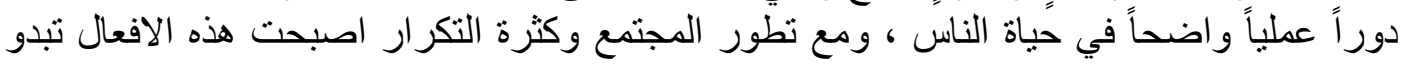

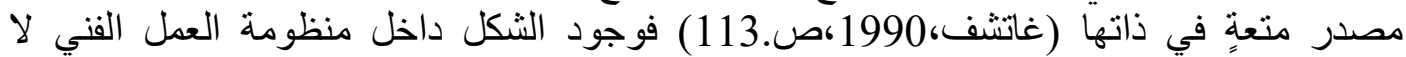

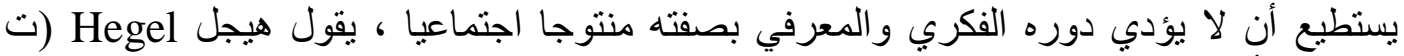

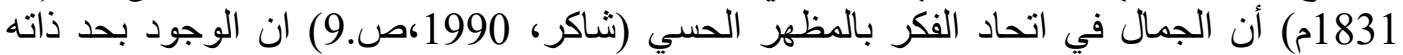

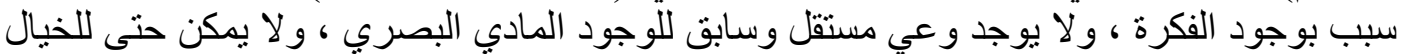

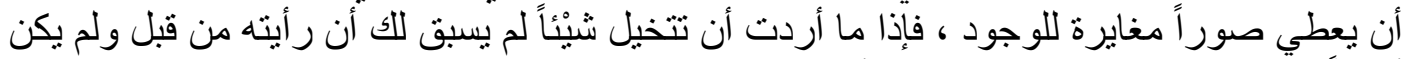

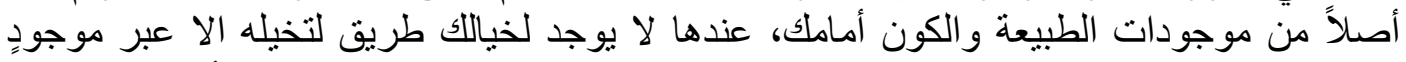

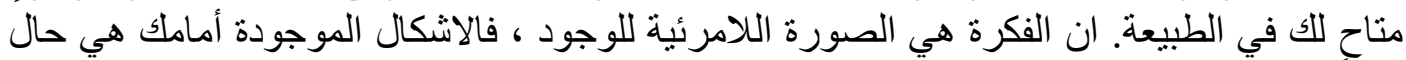

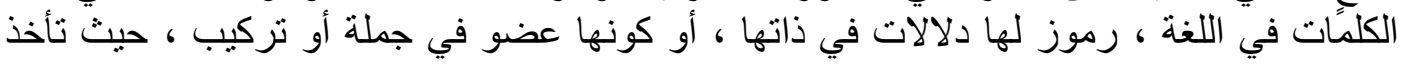

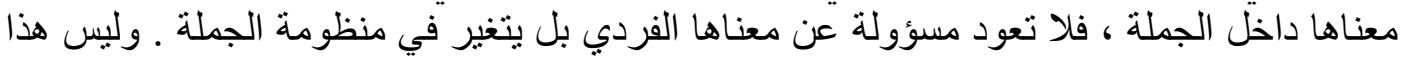

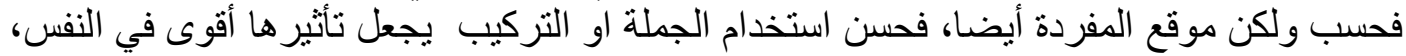

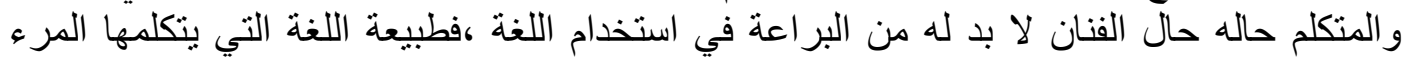

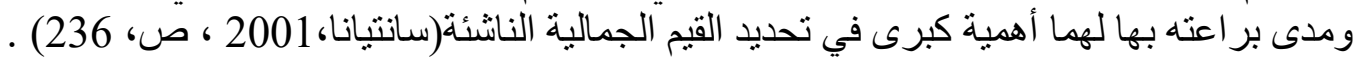

الناحية الرمزية بالشكل

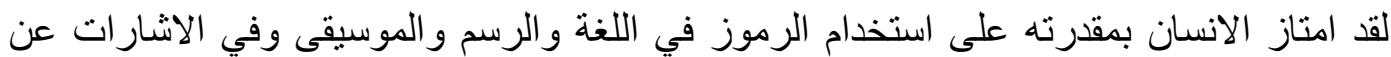

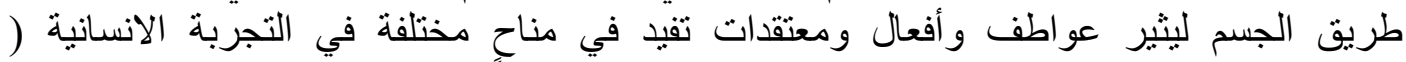

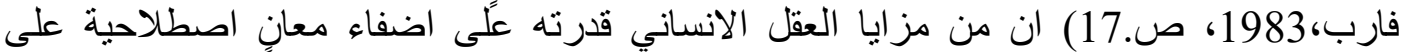

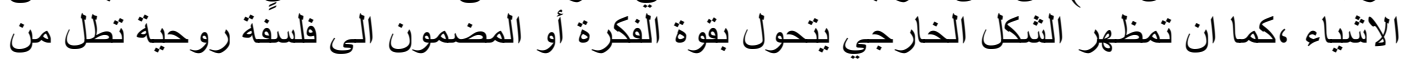

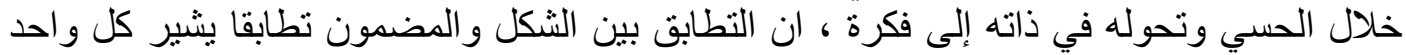

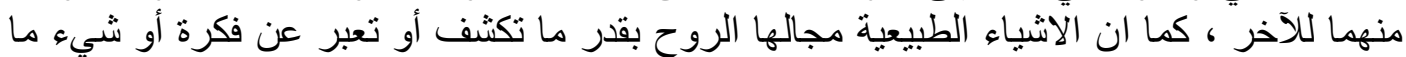

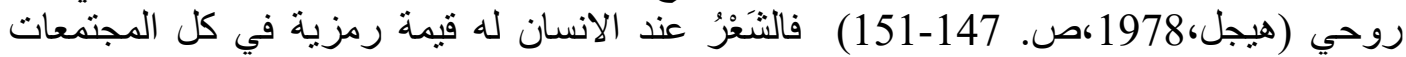

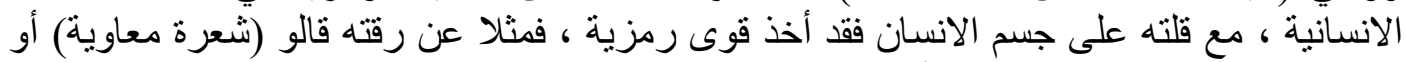

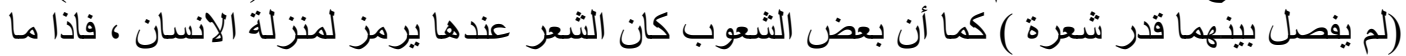

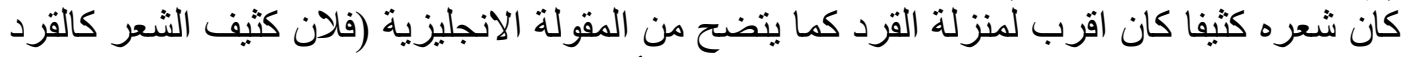

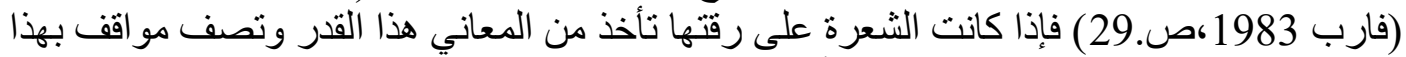

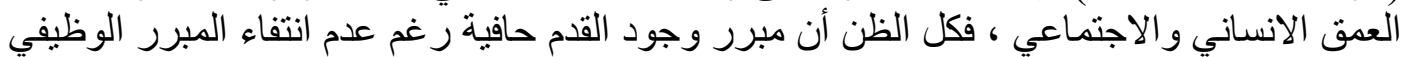

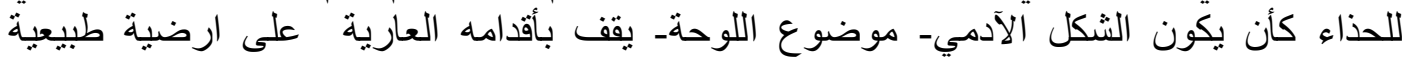

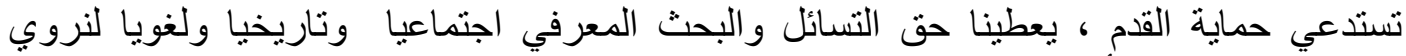

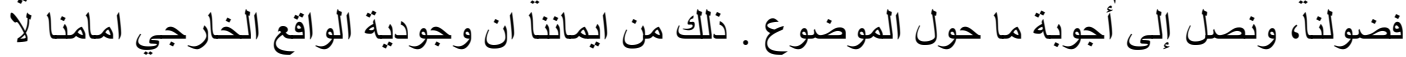
ندركها منفصلة عن ذواتنا ، ونحن نملك من الوسائل الكنائل الكثير كي نعطيها حياتتا وعمق تفكيرنا

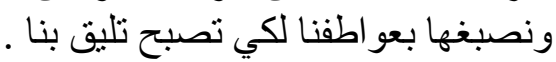




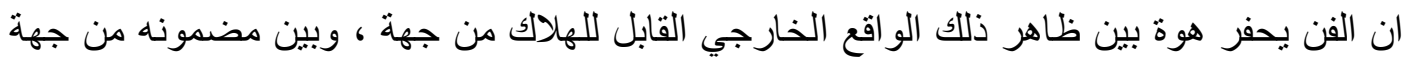

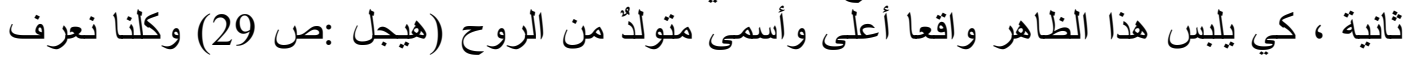

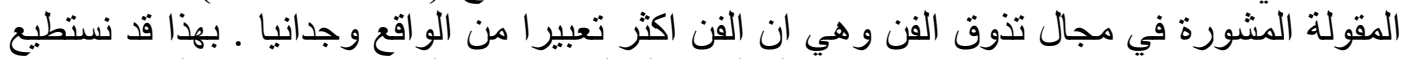

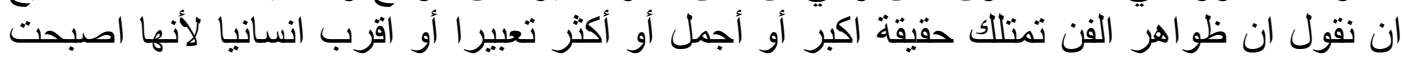

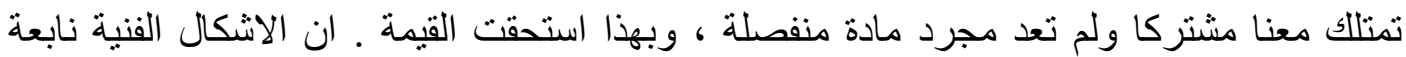

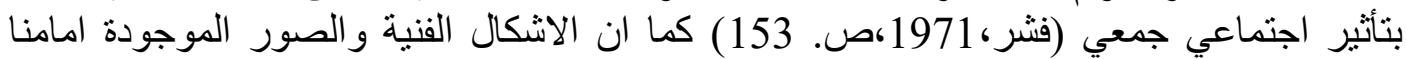

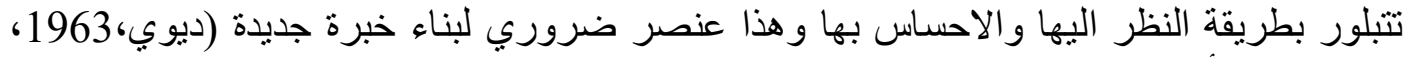

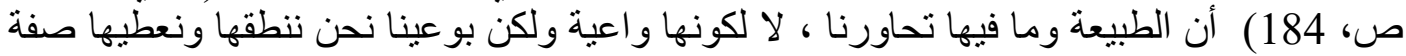

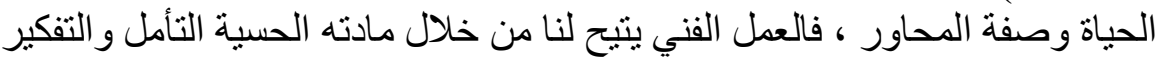

أهمية الحذاء وظيفيا

هل يحق لنا ان نسأل ما هي مبررات ظهور القدم عارية في الكثبر من الاعمال الفنبة القديمة

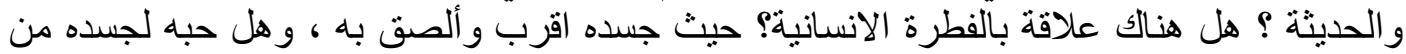

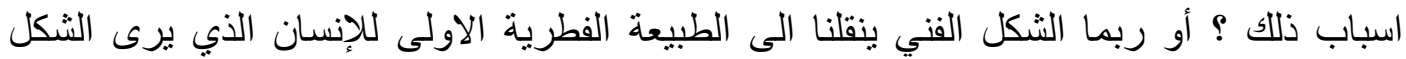

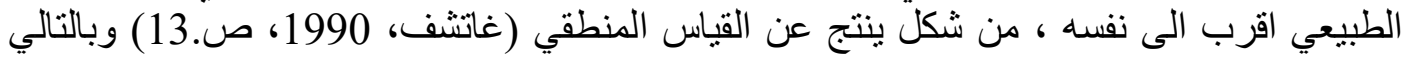

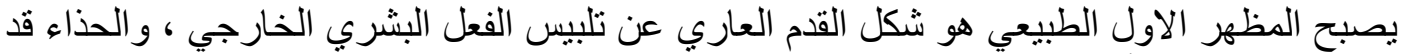

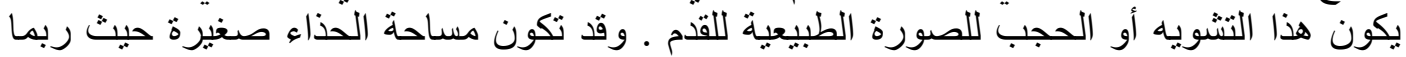

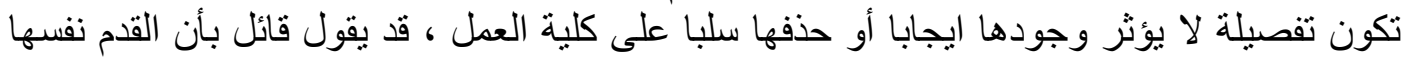

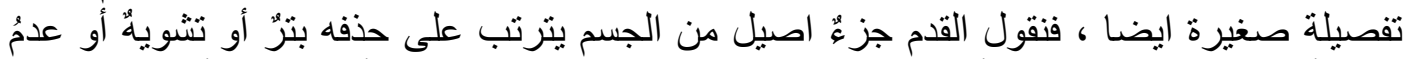

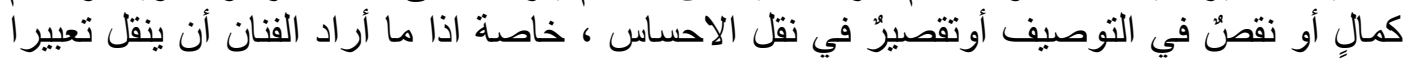

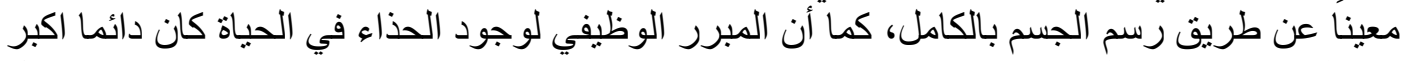

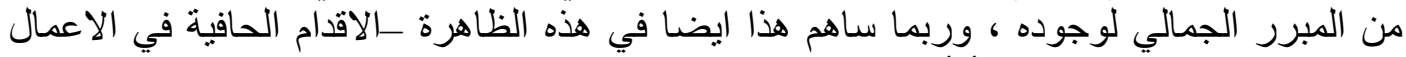

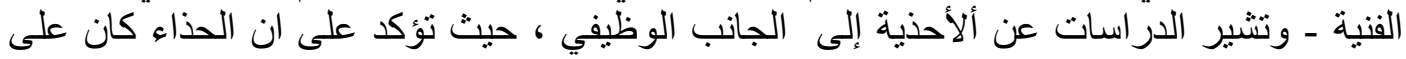

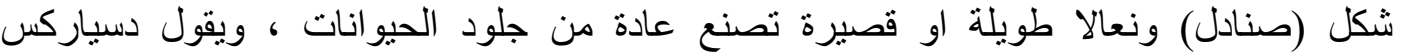
(Dicearchus)

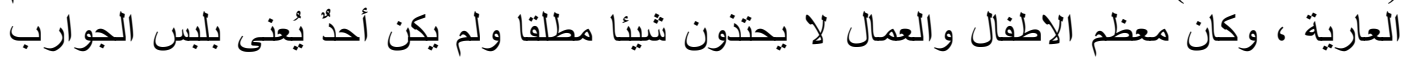

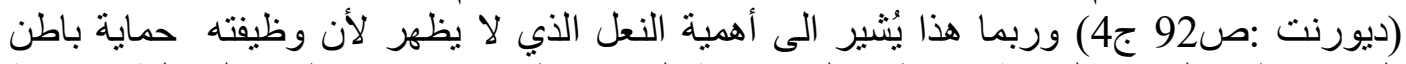

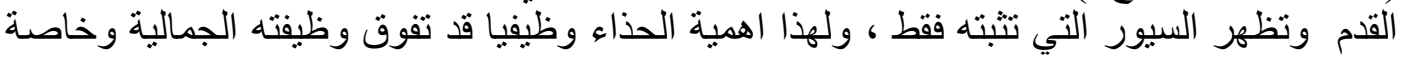

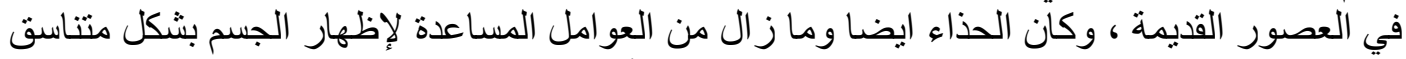

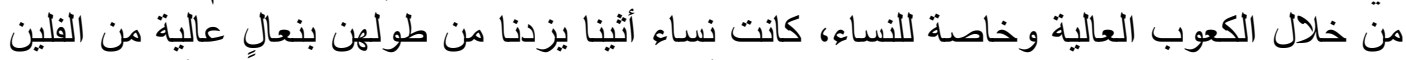

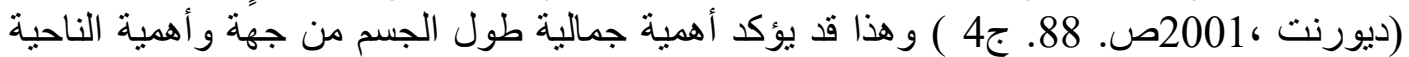

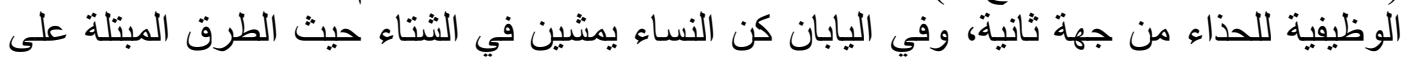

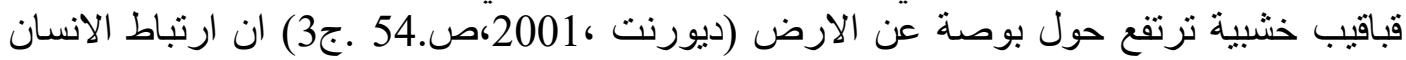

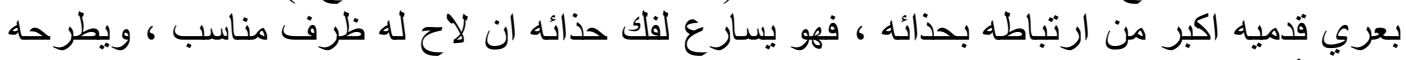

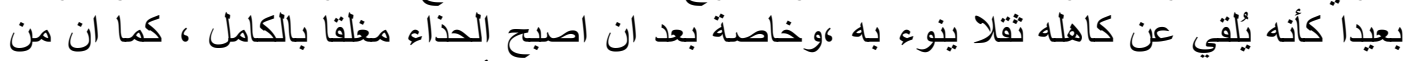

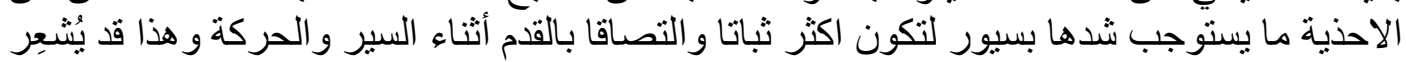

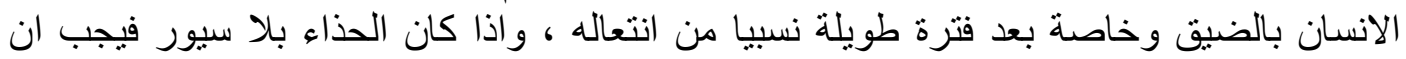

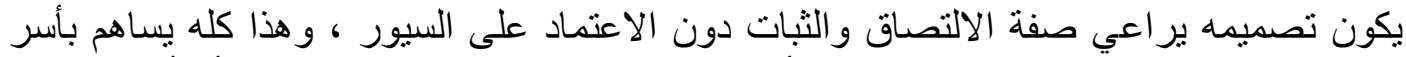

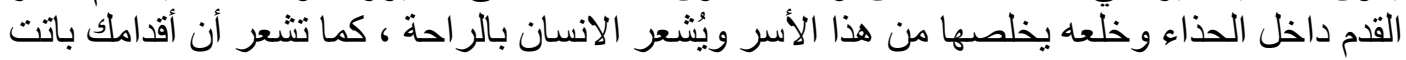
تتنفس الهواء ـ ومن اسماء الحذاء النعل و هذا اشارة كاملة لأهينته الوظيفية ، فالنعل كما اسلفنا 


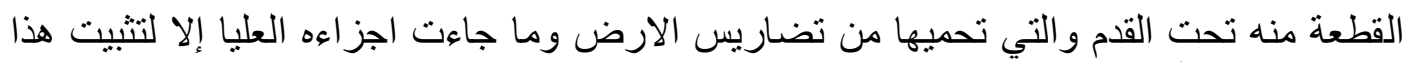

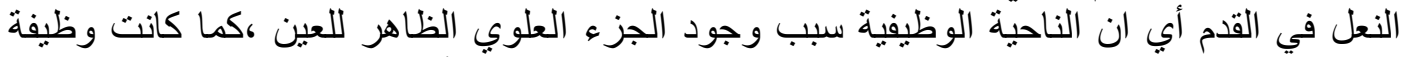

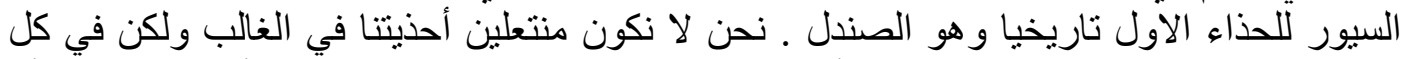

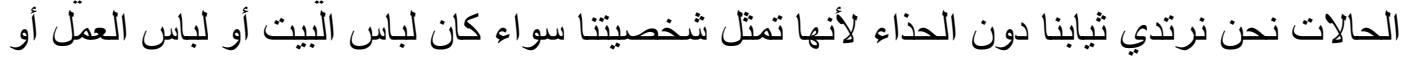

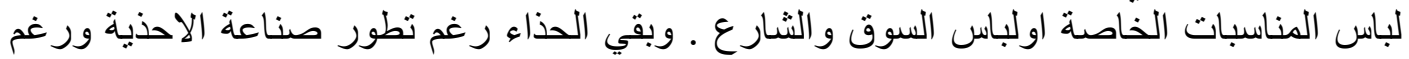

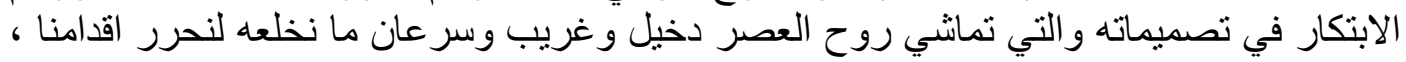

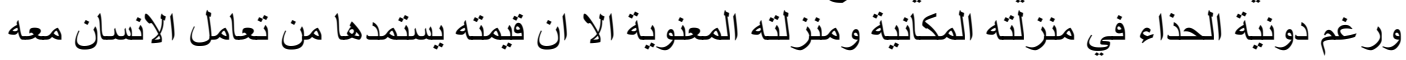

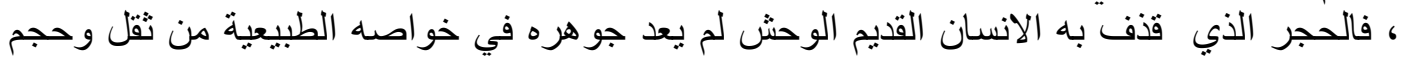

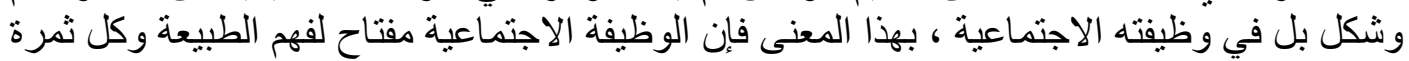

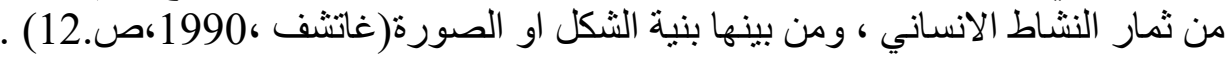

\section{الوظيفة الاجتماعية للحذاء}

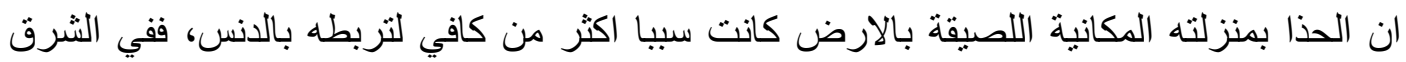

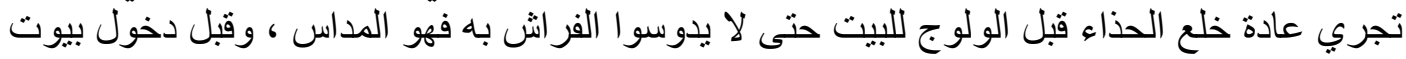

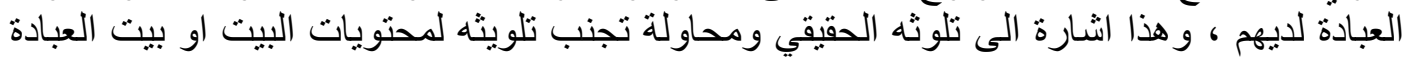

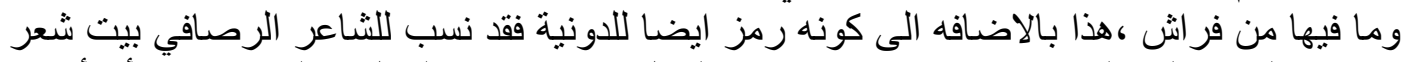

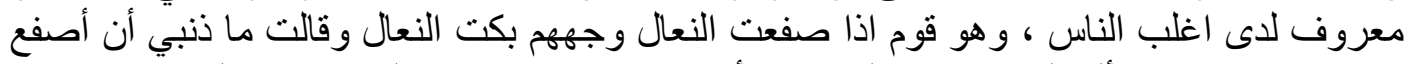

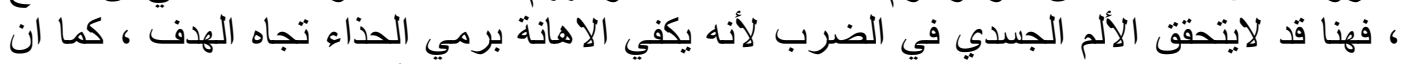

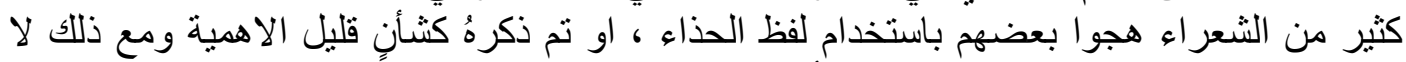

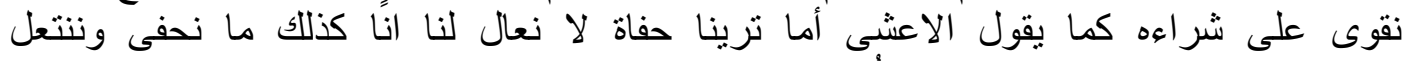

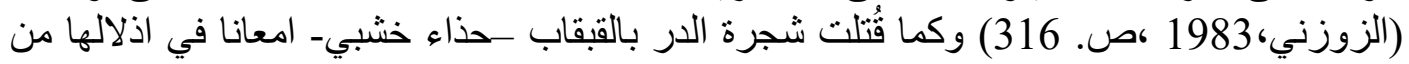

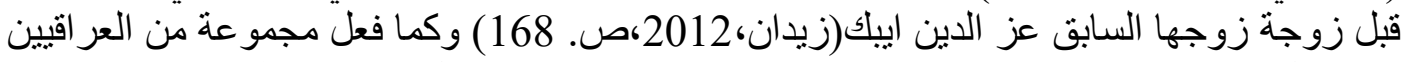

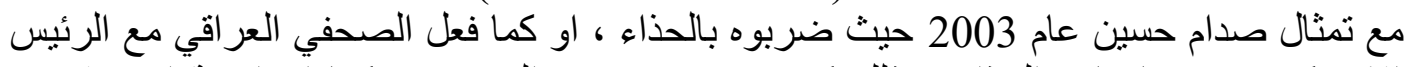

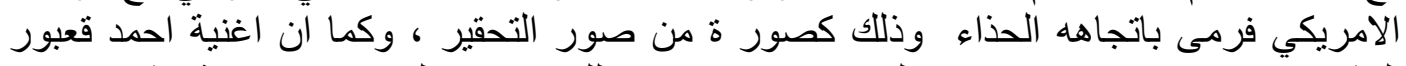

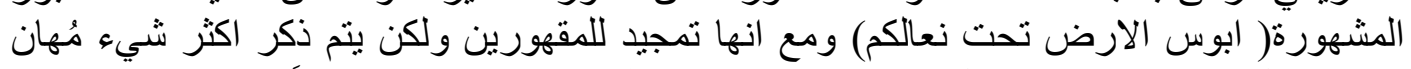

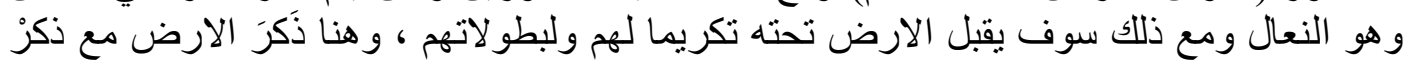

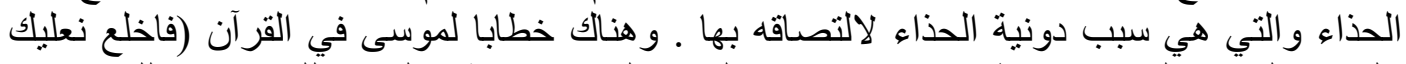

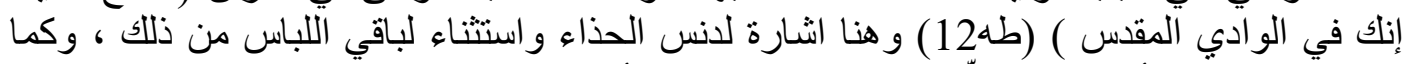

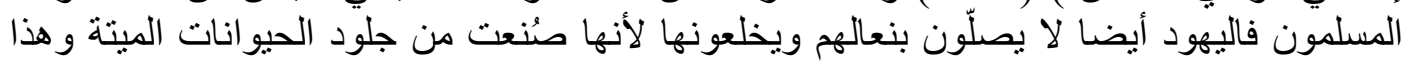

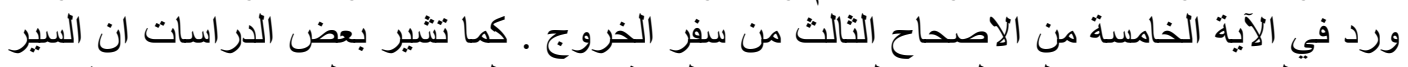

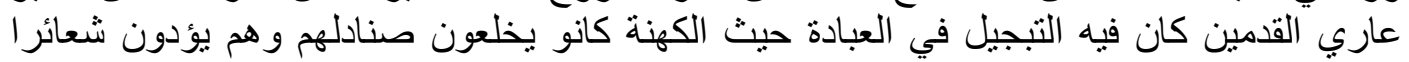

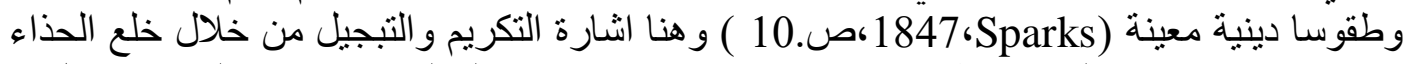

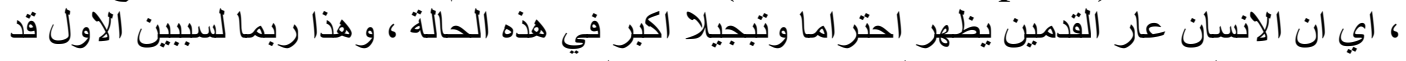

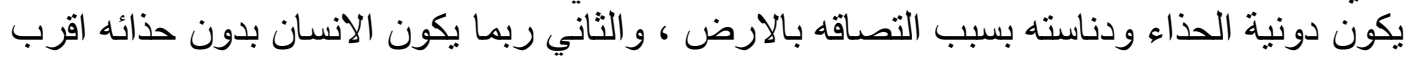

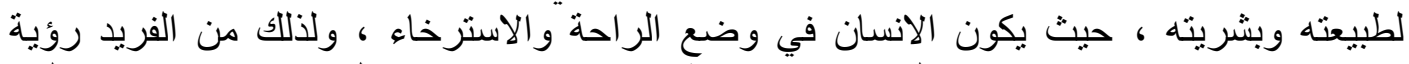

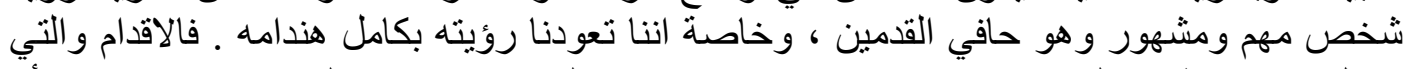

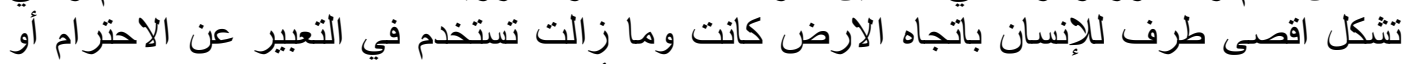

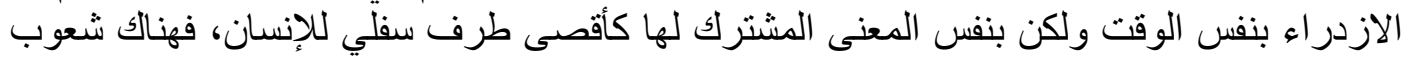

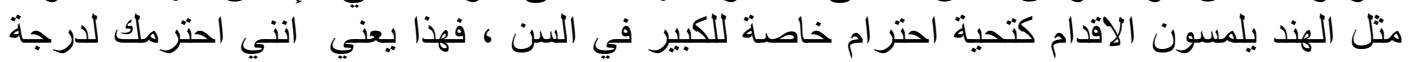

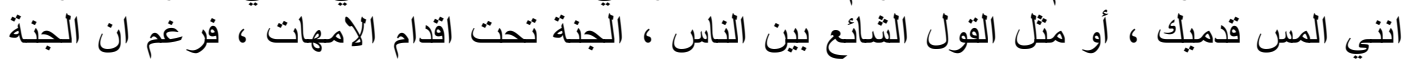




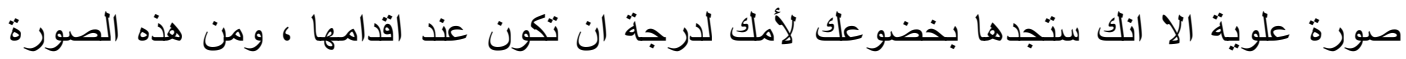

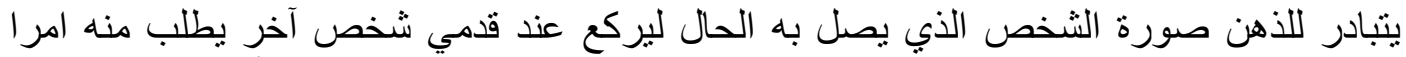

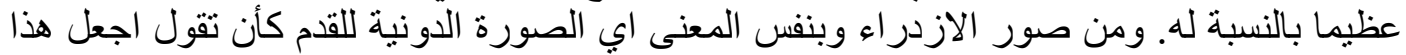

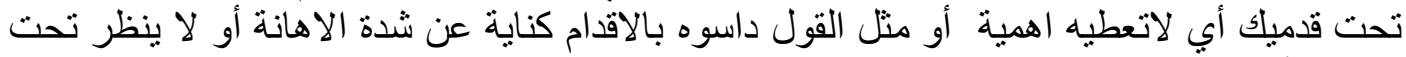

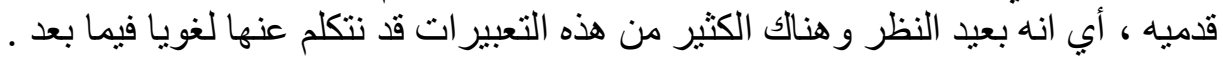

\section{الصورة الفطرية للإنسان الحافي}

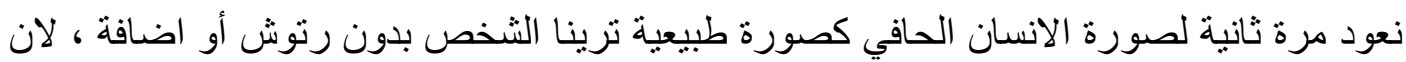

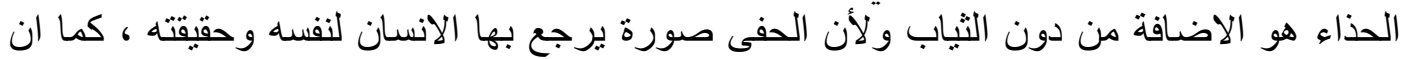

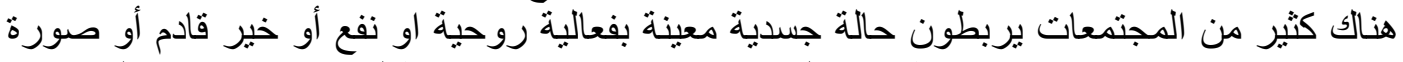

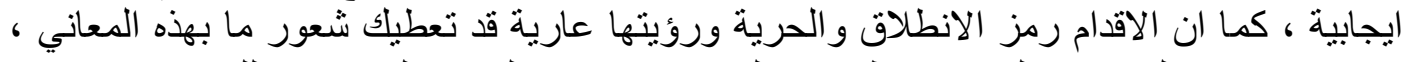

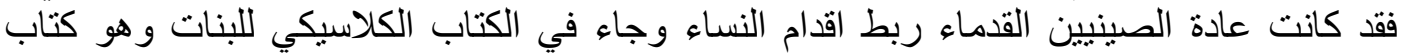

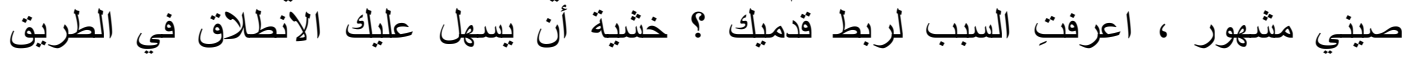

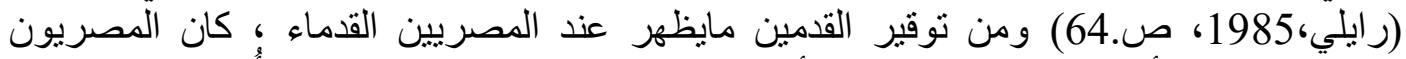

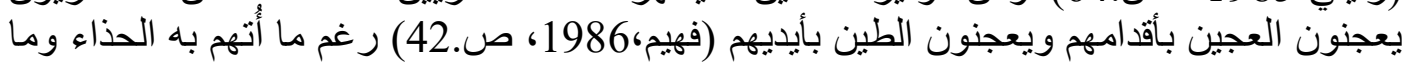

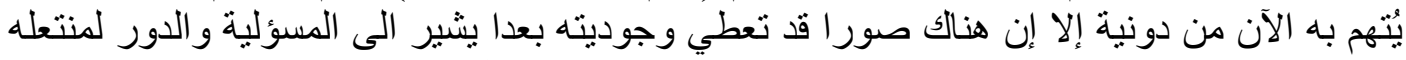

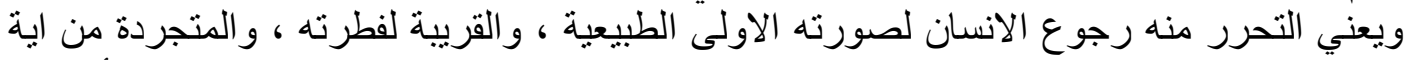

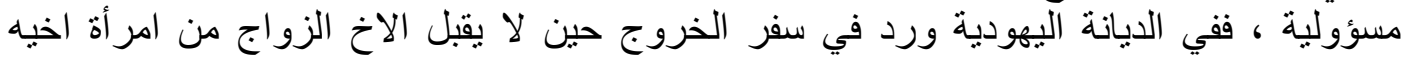

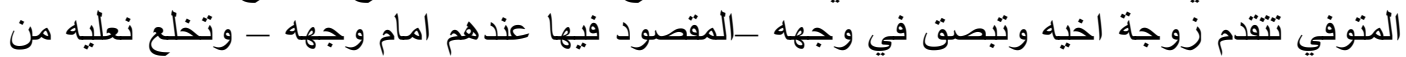

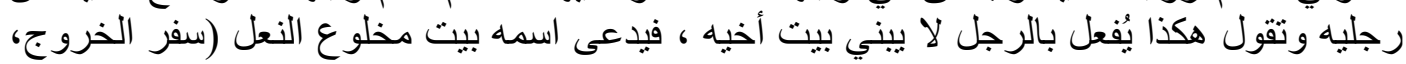

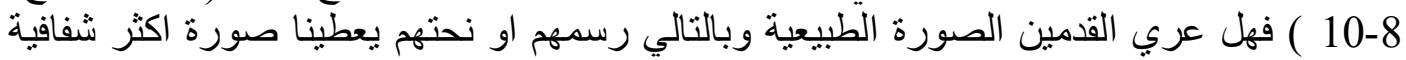

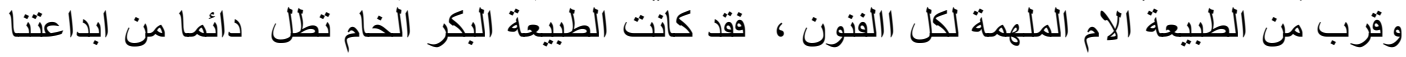

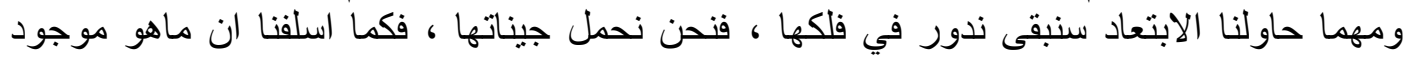

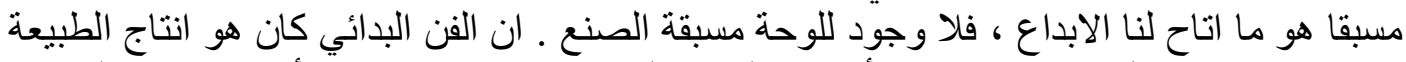

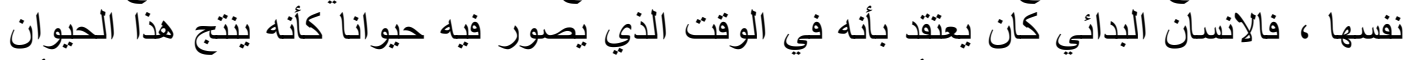

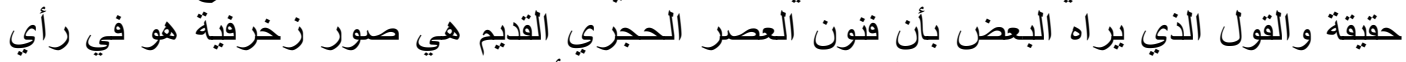

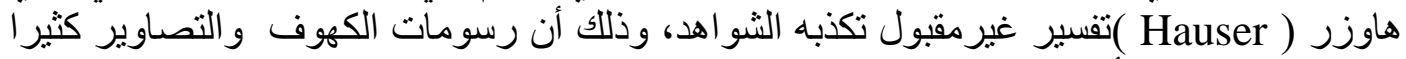

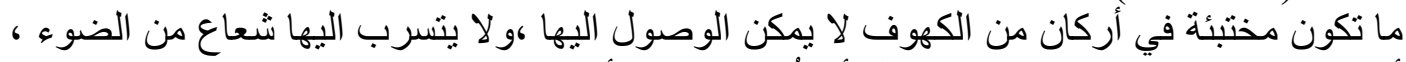

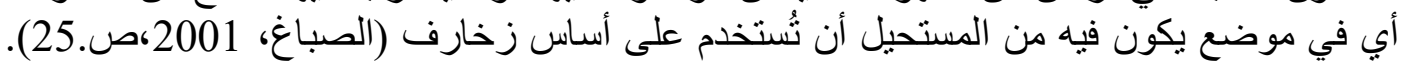

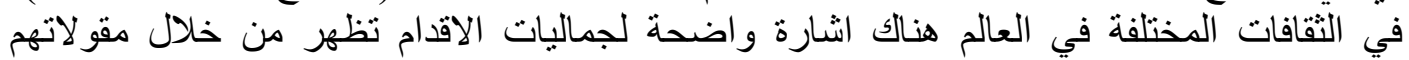
وامثالهم . المثاف

\section{الاقدام الحافية في اقوال بعض الثعوب وأمثالهم}

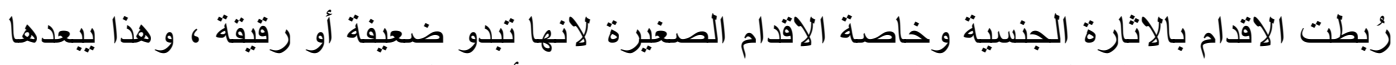

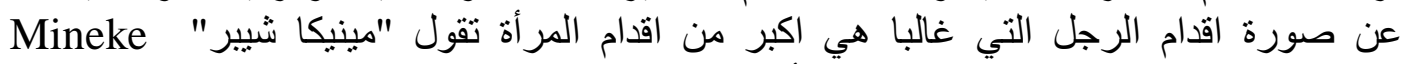

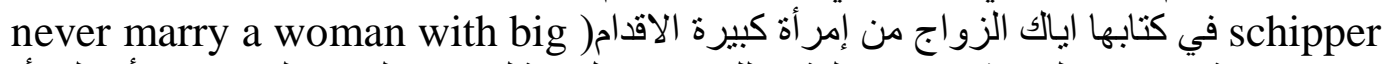

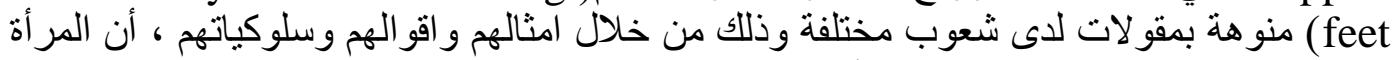

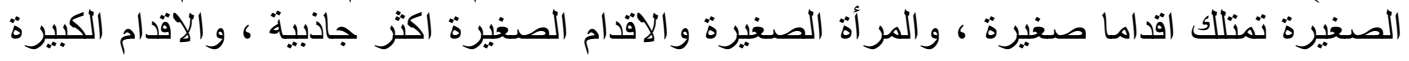

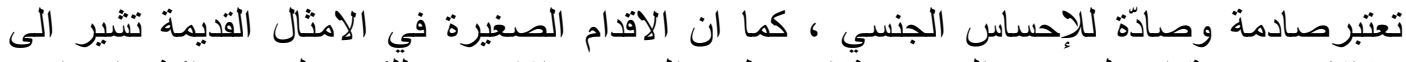

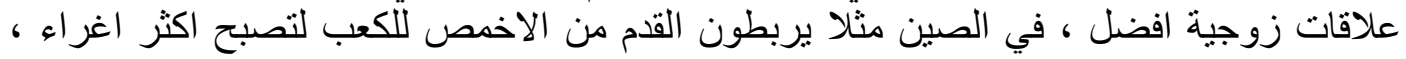


وفي ملاوي في موزمبيق يحذرون من النساء ذات الاقدام الكبيرة كأن يقولو ال الا تتزوج كبيرة الاقدام

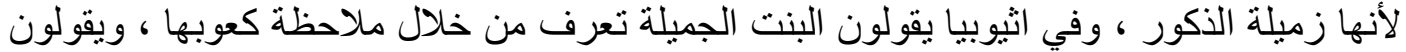

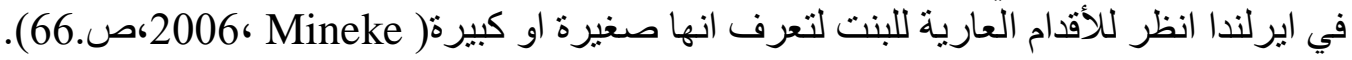

\section{القدم كعضو جميل يستأهل التزيين}

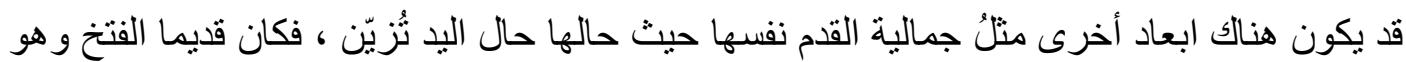

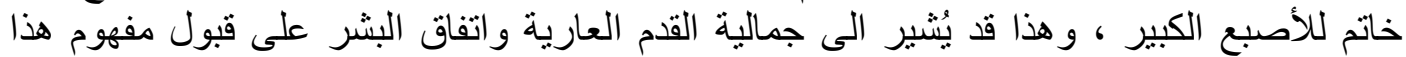

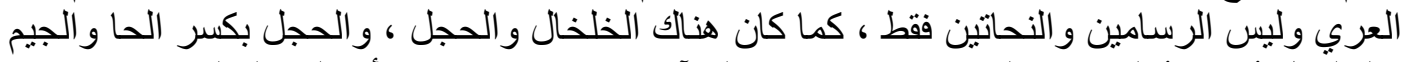

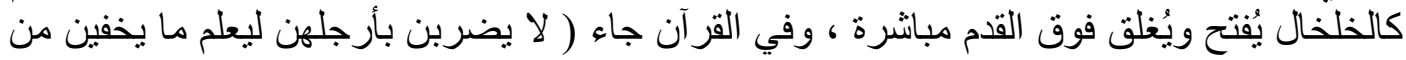

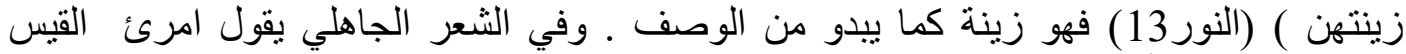

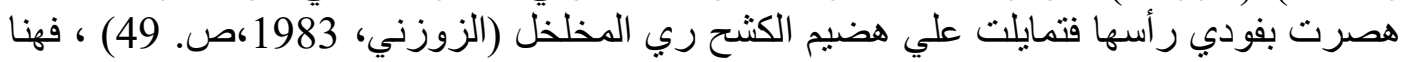

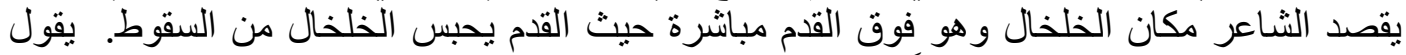

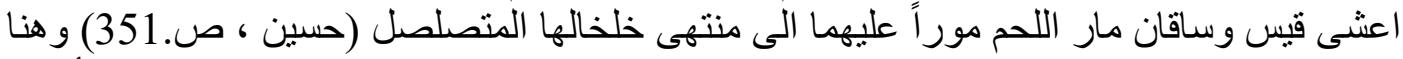

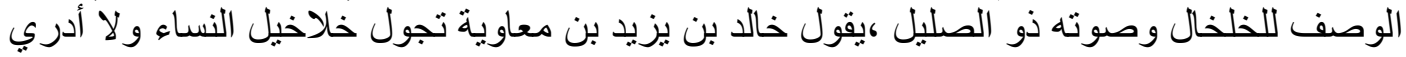

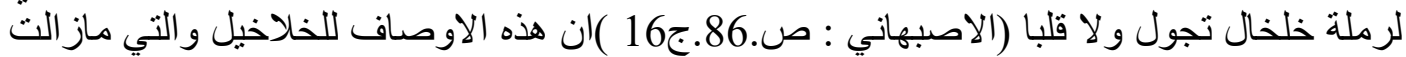

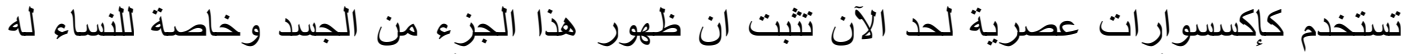

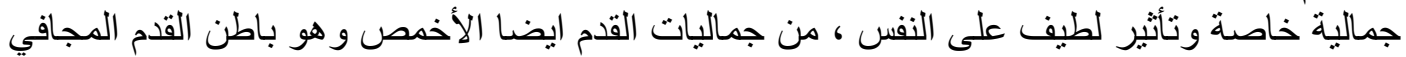

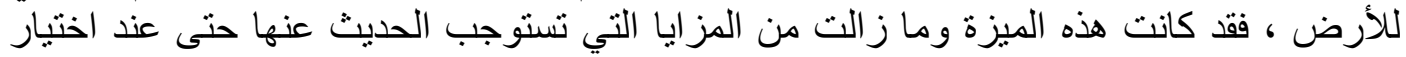

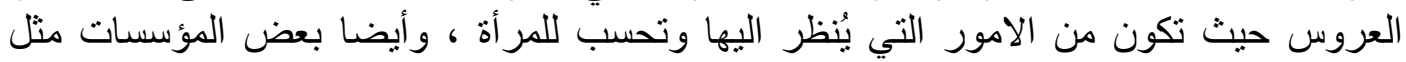

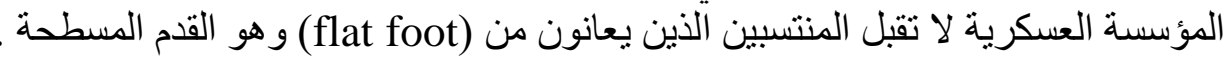

\section{ألقدم تشريحيا}

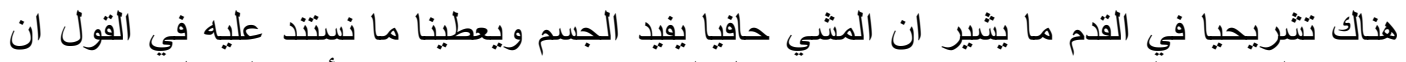

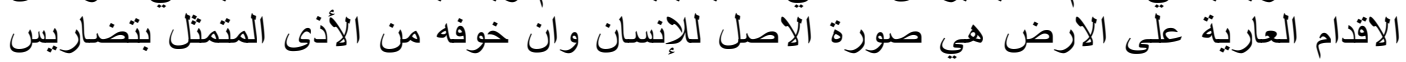

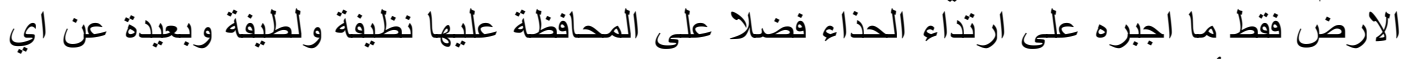

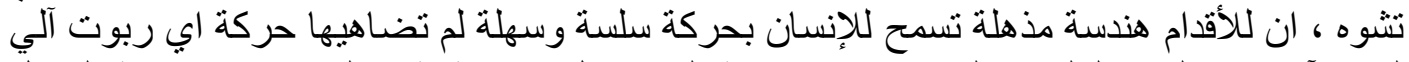

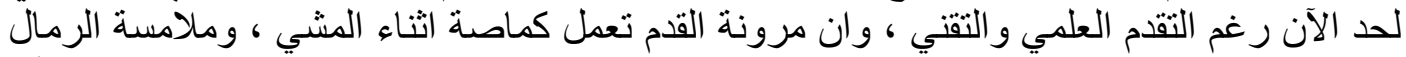

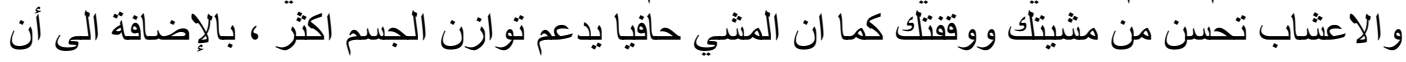

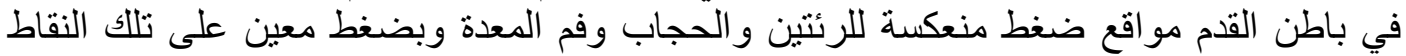

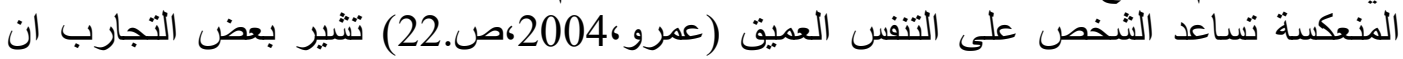

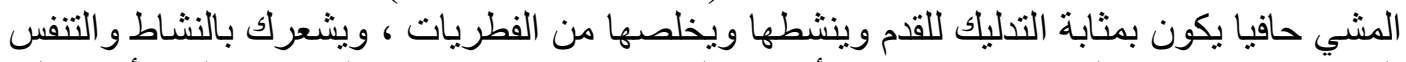

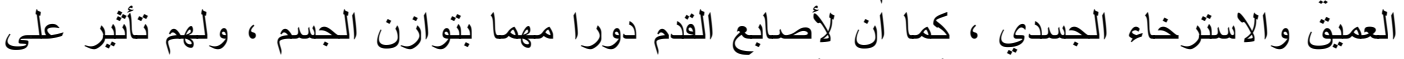

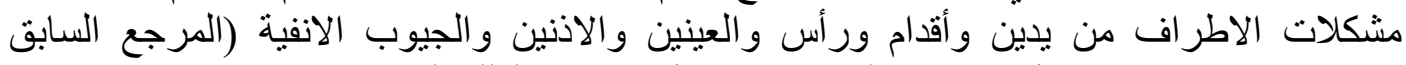

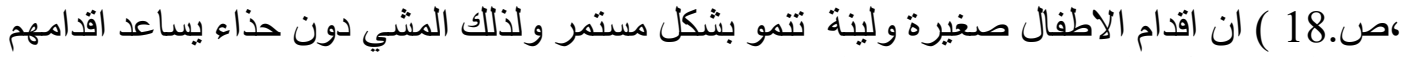

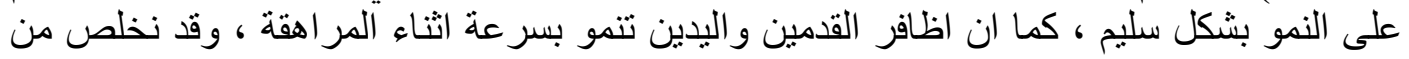

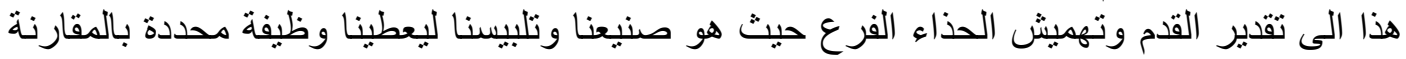

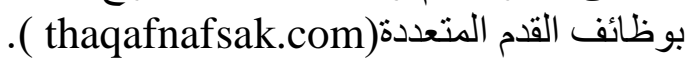




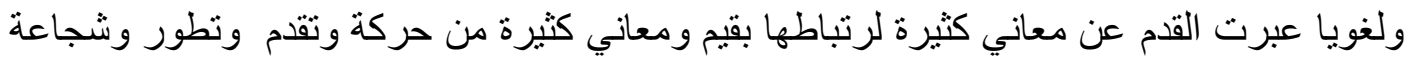

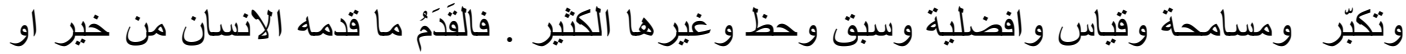

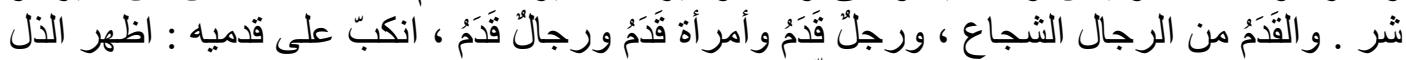

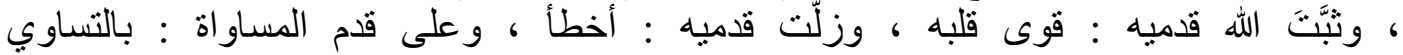
(Almaany.com /page 1-2) و هنالك الكثير الكثير من المعاني و الاصطلاحات كانت القدم طريقا

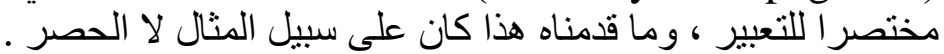

\section{الفصل الثالث}

\section{التحليل الشكلي فنيا وجماليا}

\section{أهمية الثكل البصري كمدخل للروئيا}

لقد بحثنا سابقا شكل القدم و اقعيا من نو احي تاريخية و اجتماعية ولغوية وتنشريحية ، أب القدم كما تتيح

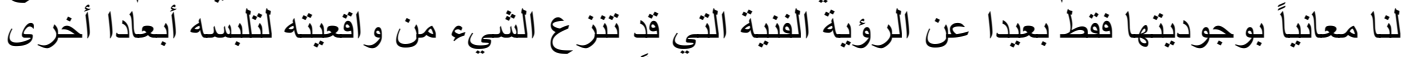

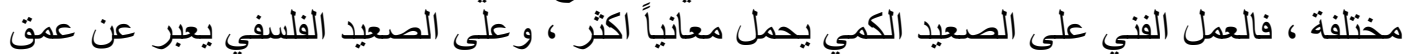

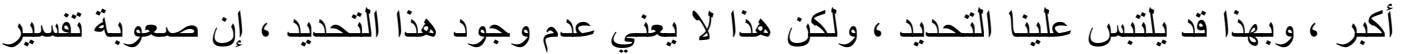

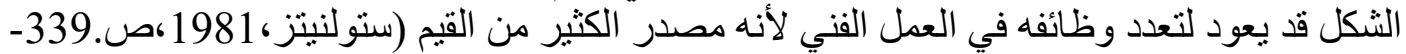

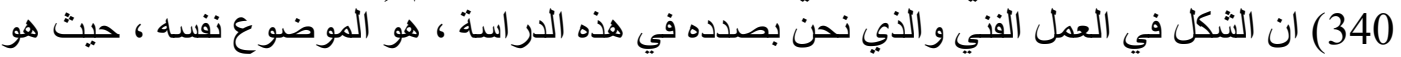

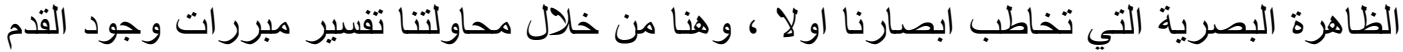

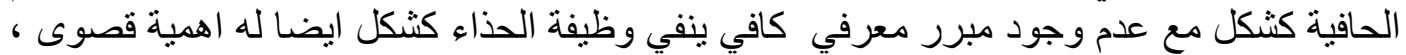

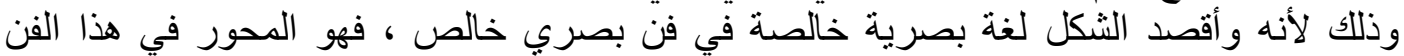

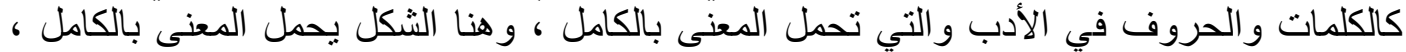

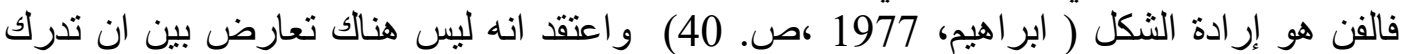

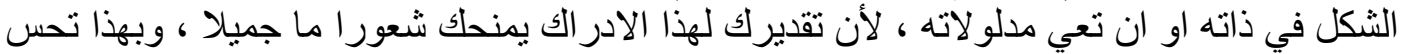

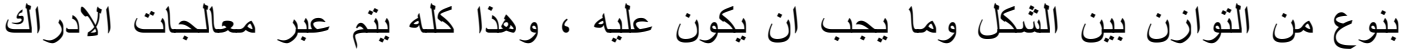
للموضوع ، فالمدخلات يتم معالجتها معرفيا بالادر الك و التفكير و والخيال و اللغة لتحصل التحل الاستجابات الادرات 


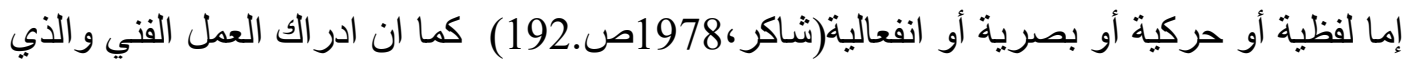

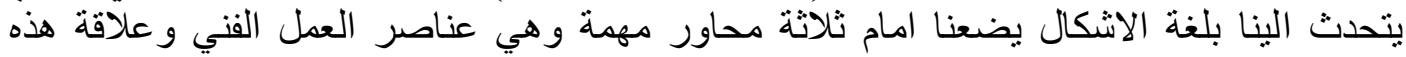

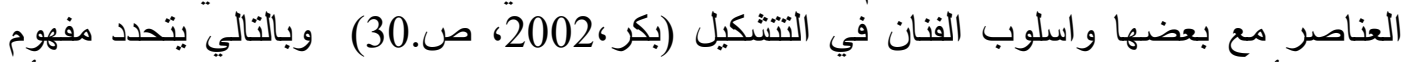

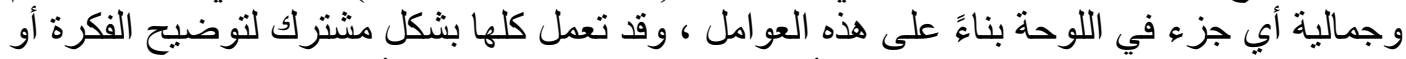

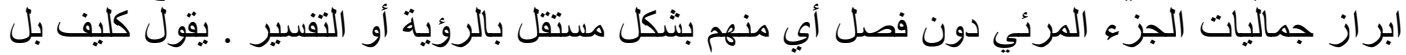
(Clive Bill ) خطوطا أو كتلا أو مسطحات لونية (المرجع السابق، ص. 33 لو ) ) .

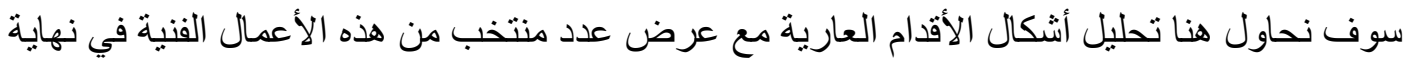

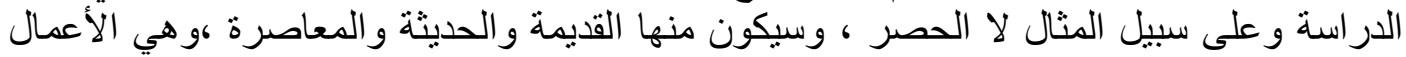

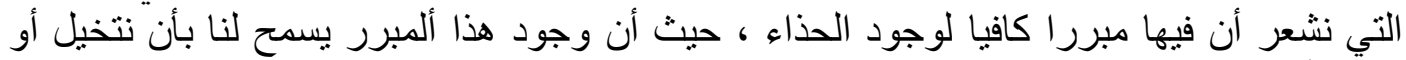

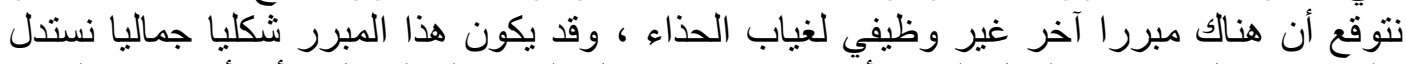

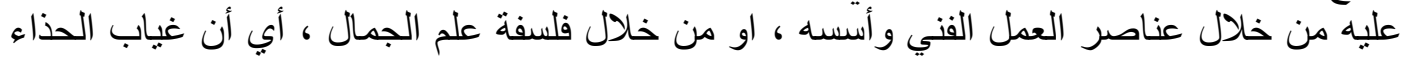

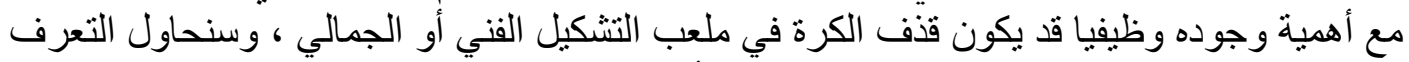

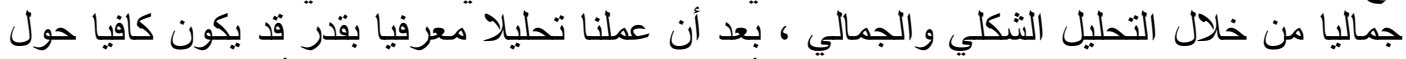

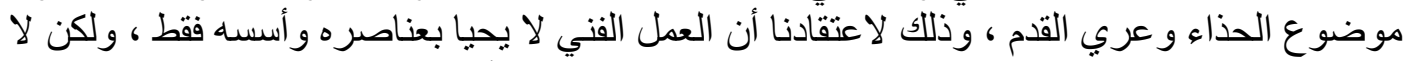

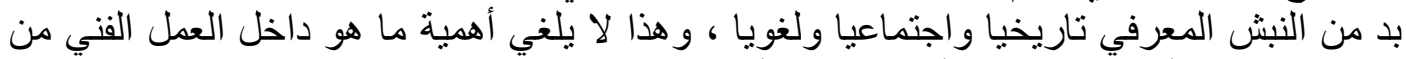

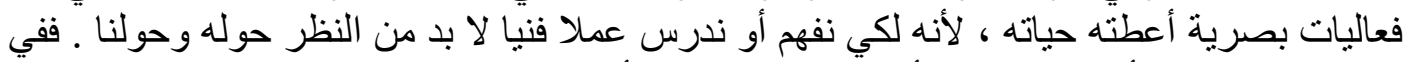

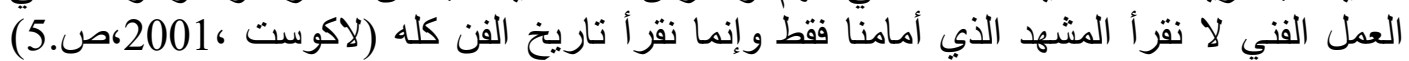

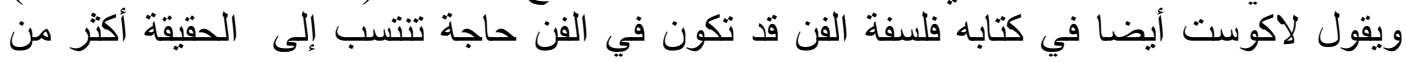

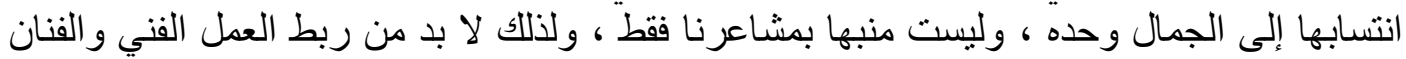

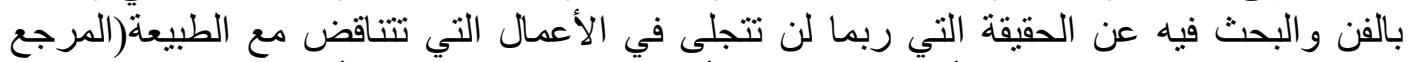

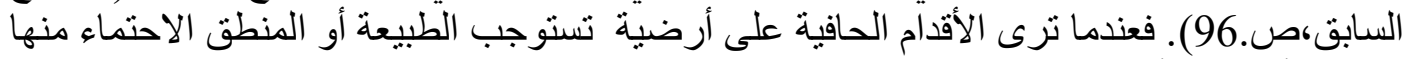

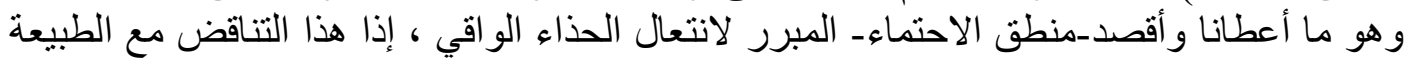

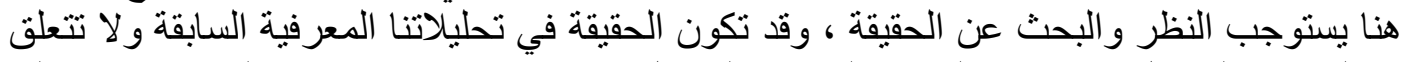

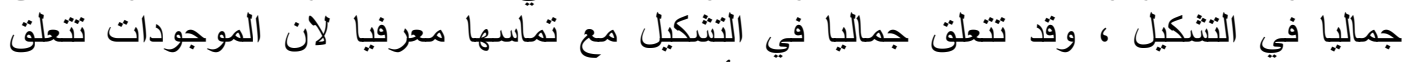

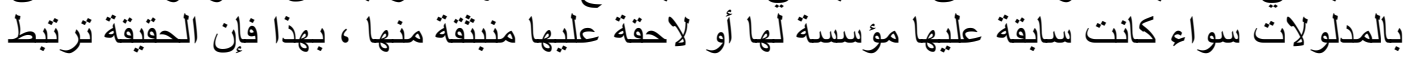

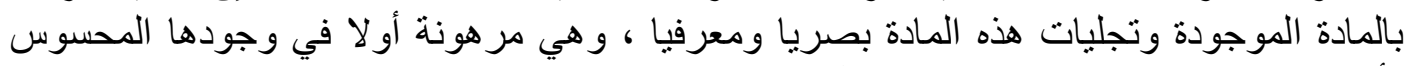

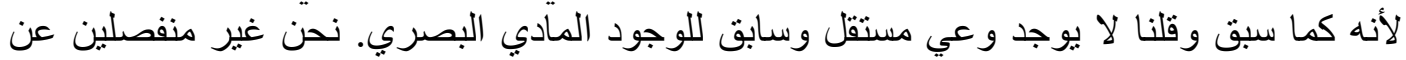

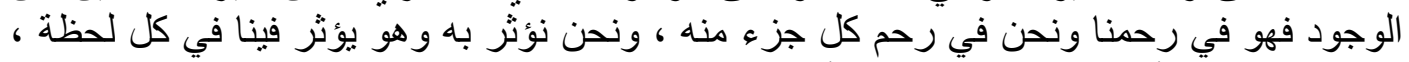

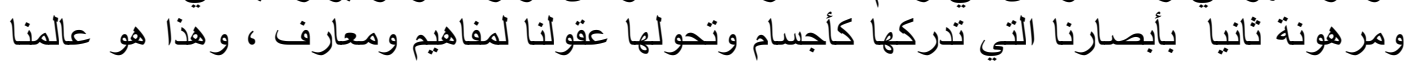

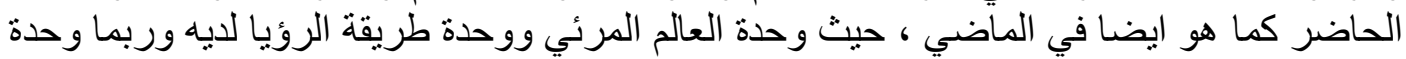

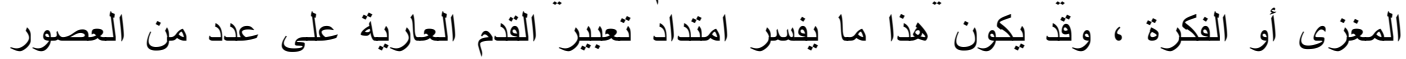

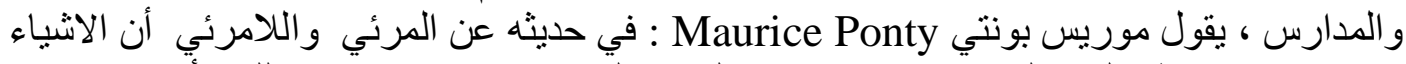

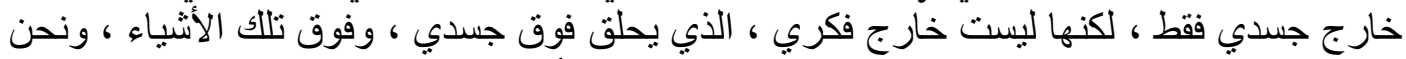

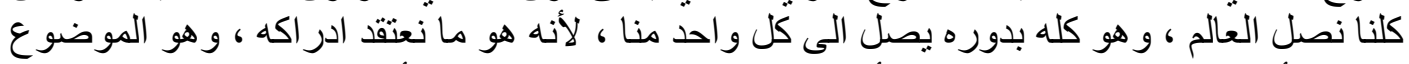

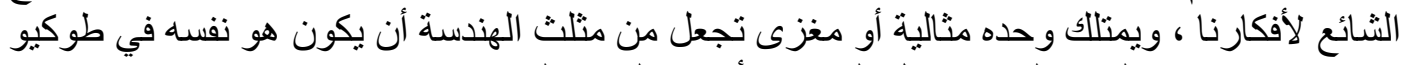

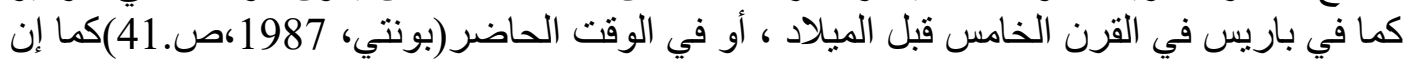

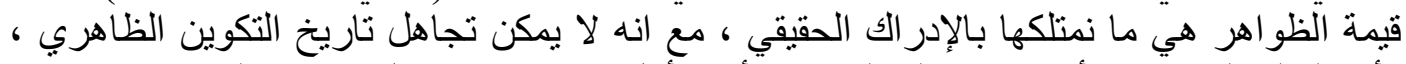

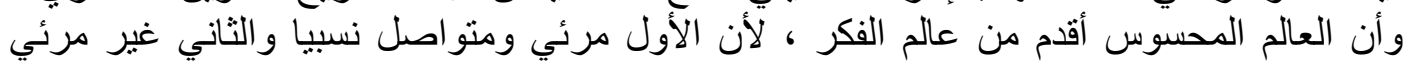

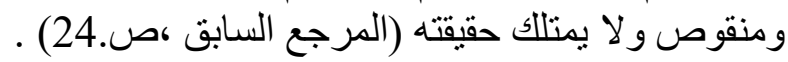




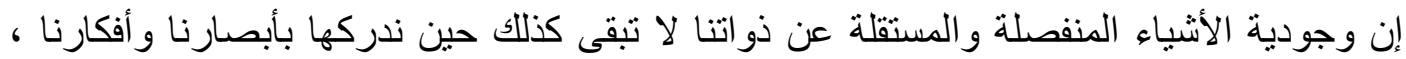

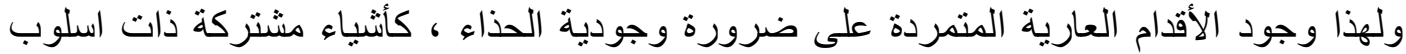

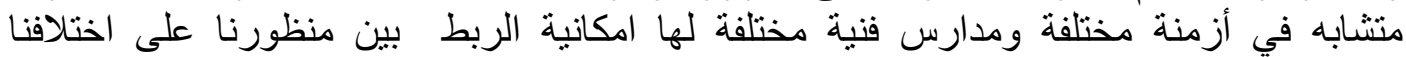

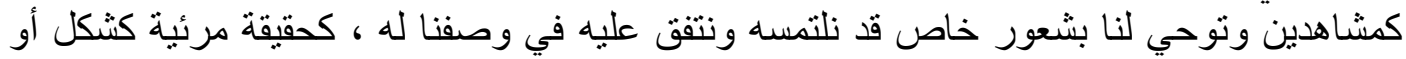

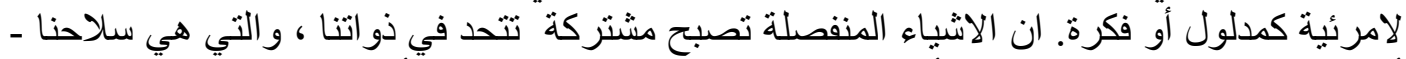

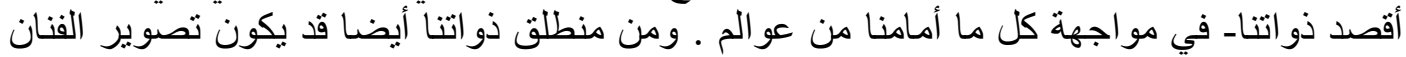

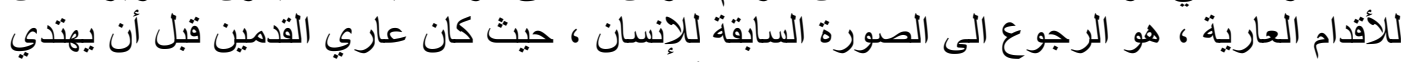

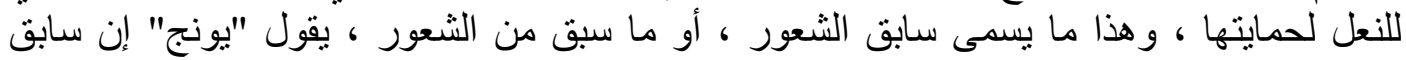

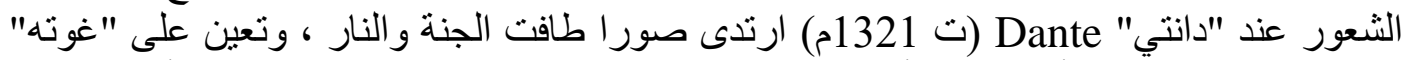
Goethe

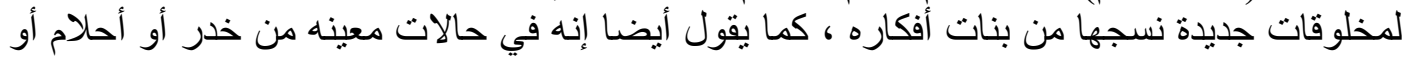

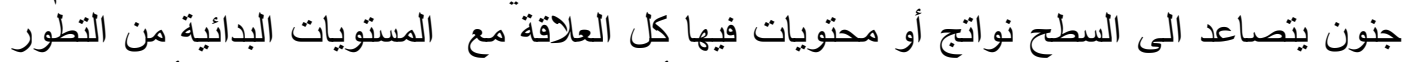

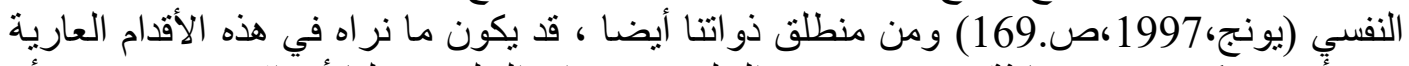

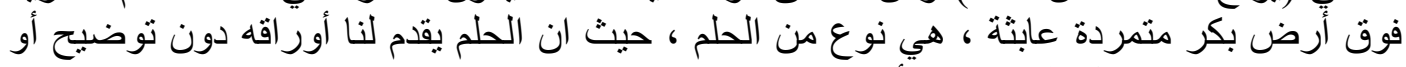

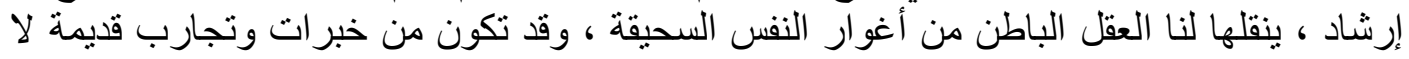

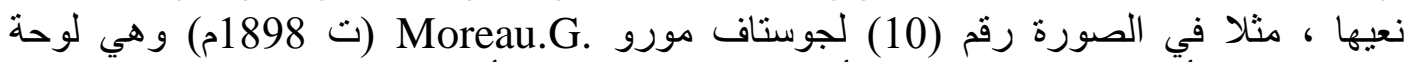

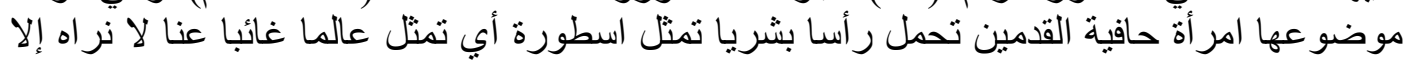

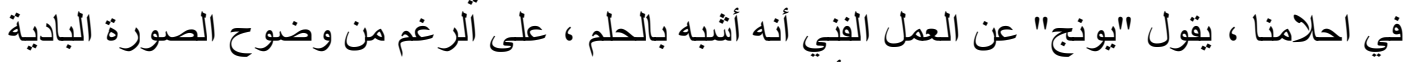

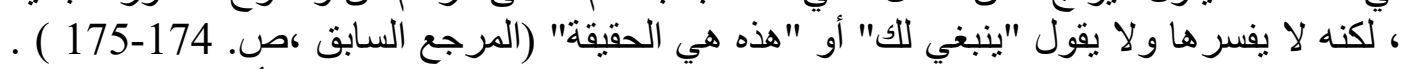

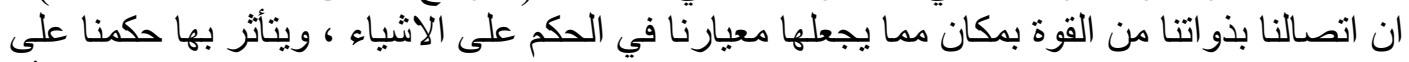

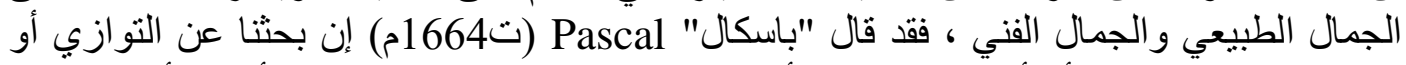

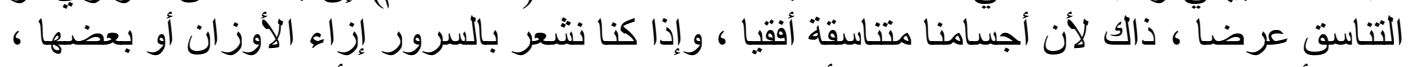

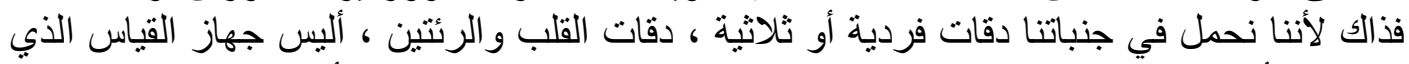

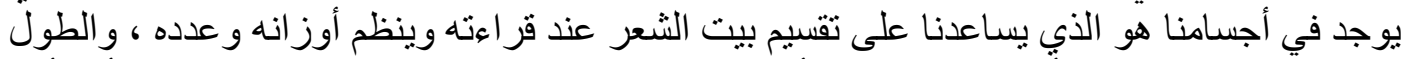

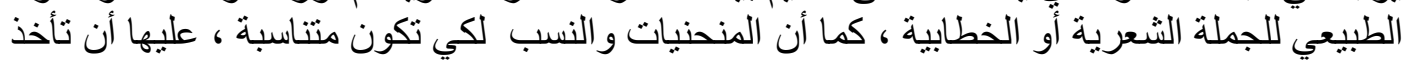

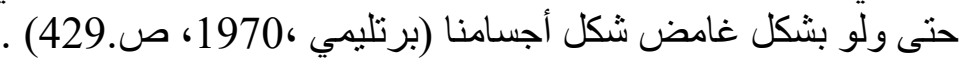

الناحية الرمزية ولية بندية

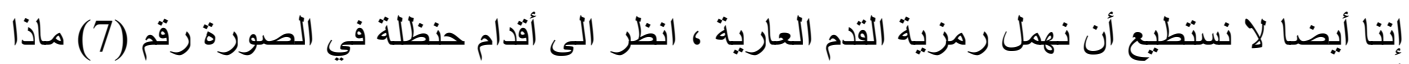

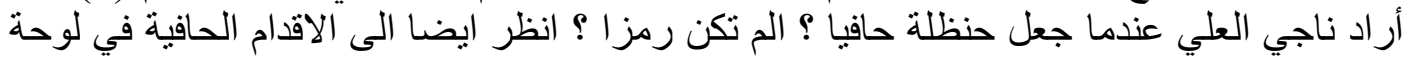

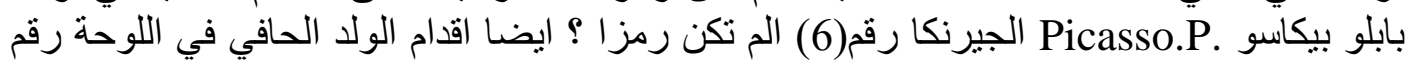

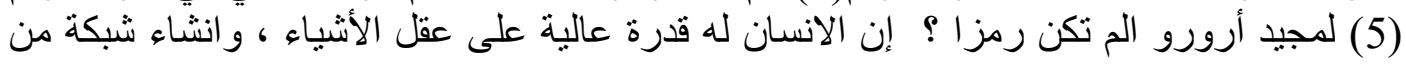

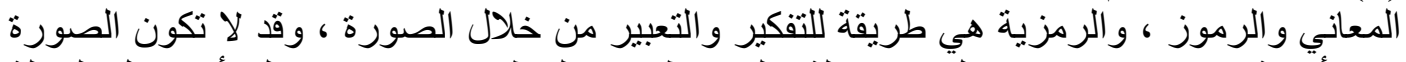

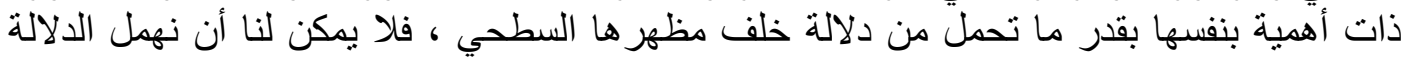

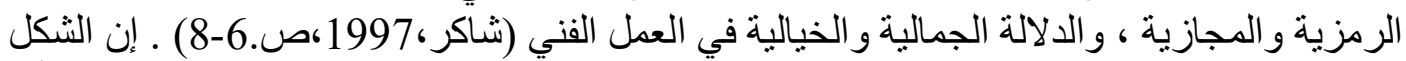

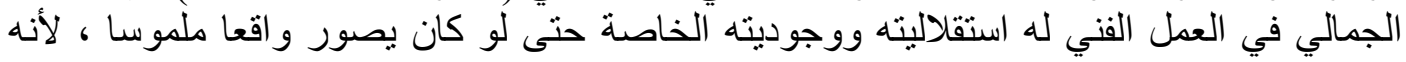

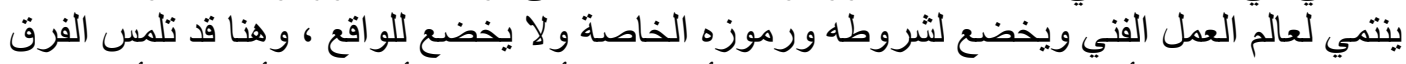

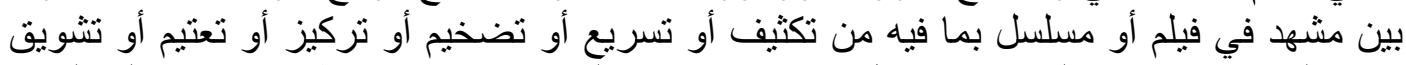

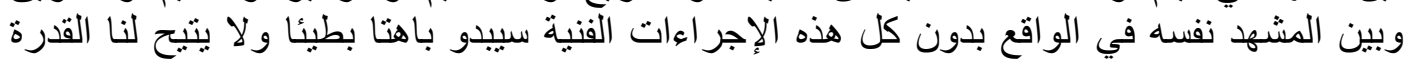




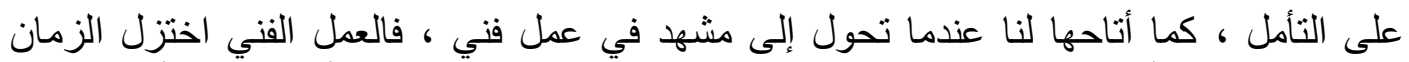

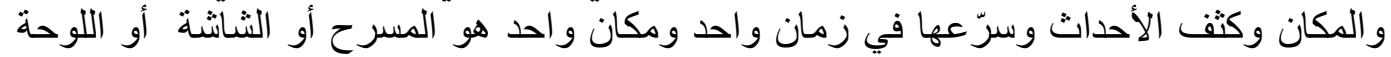

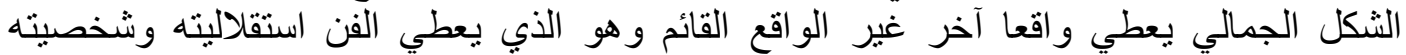

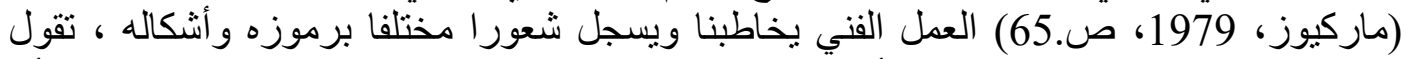

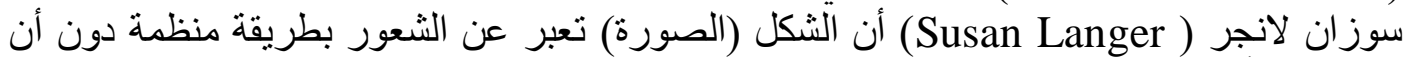

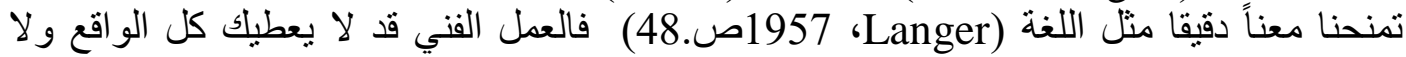

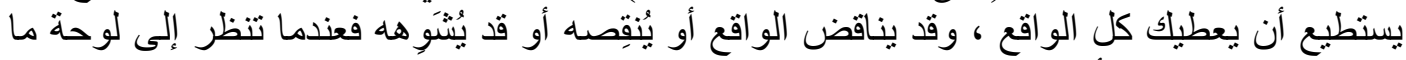

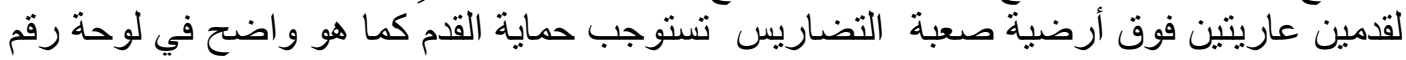

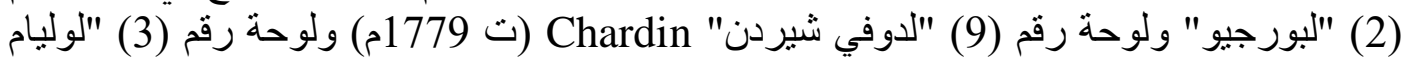
ووترهاوس" وقد يعتريك تساءل عن هدف هذا العري، وقد العد تثير فيك انفعالا يدفعك لإكمال الصورة

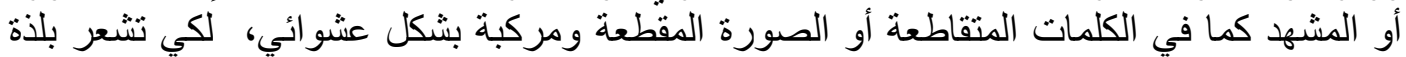

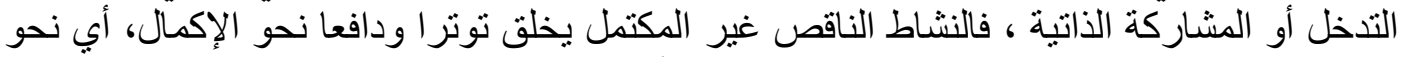

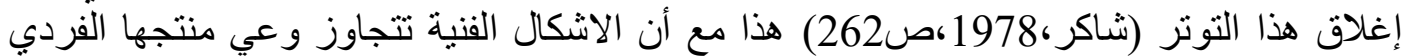

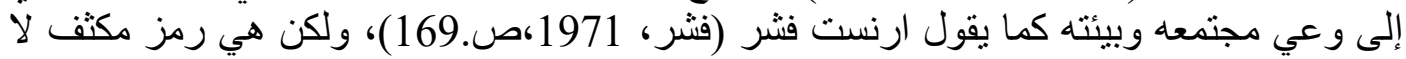

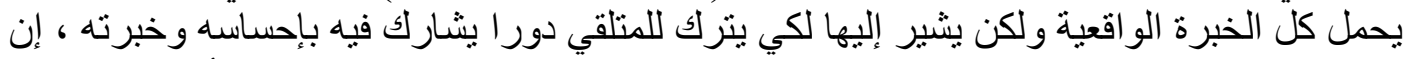

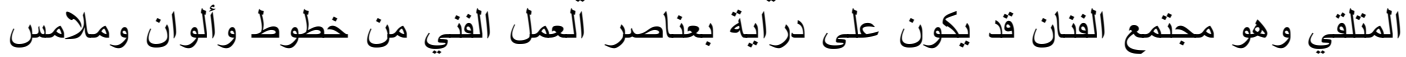

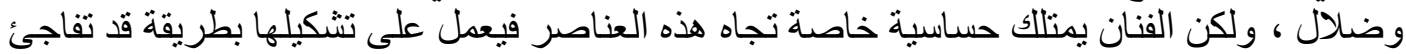

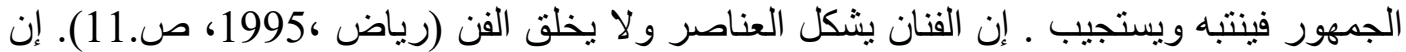

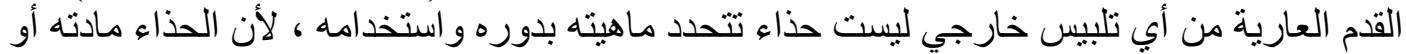

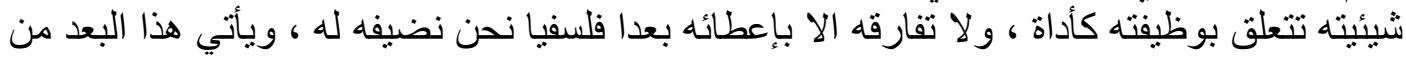

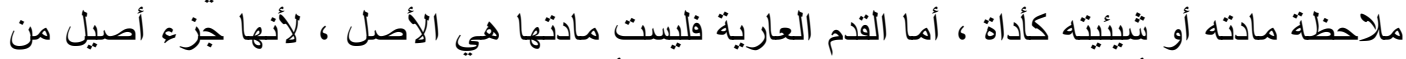

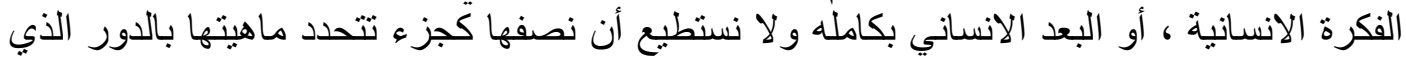

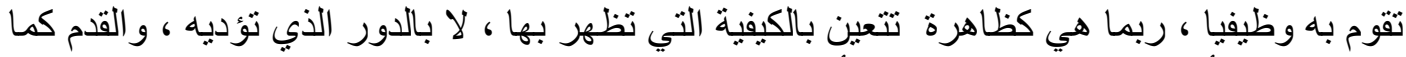

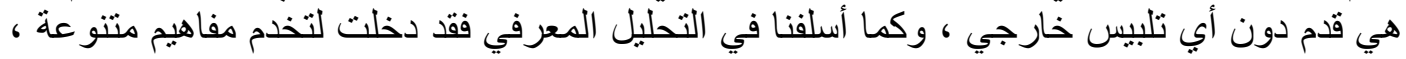

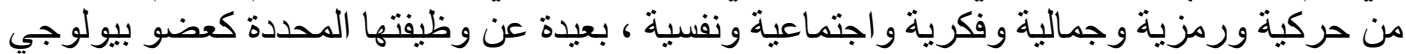

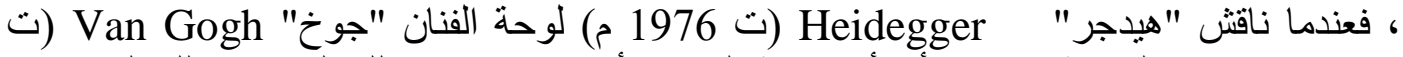

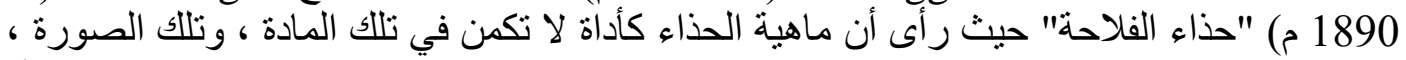

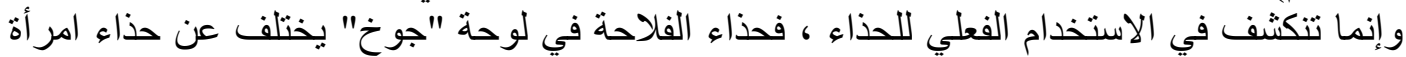

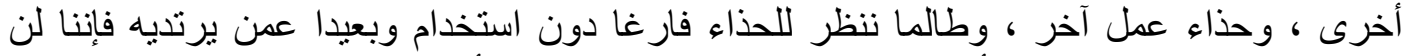

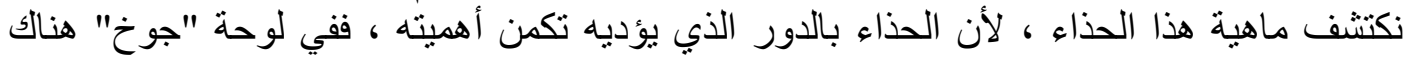

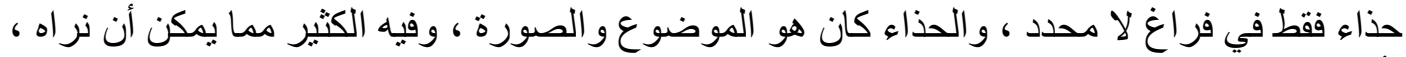

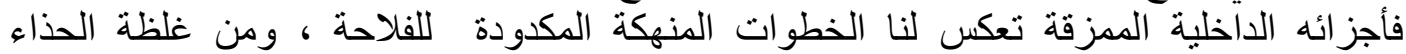

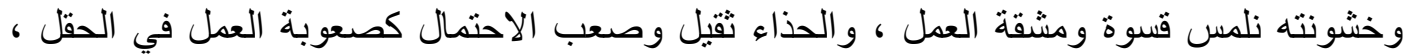

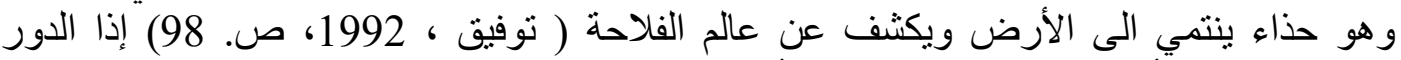

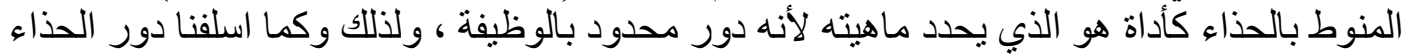

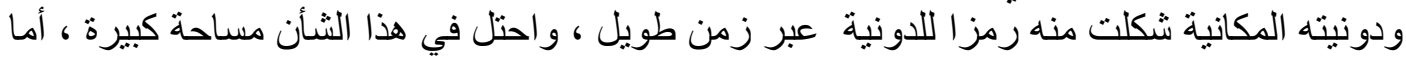

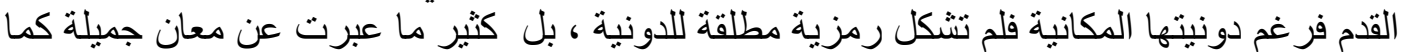

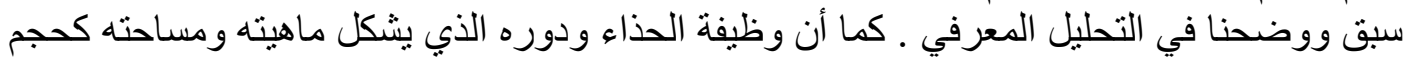

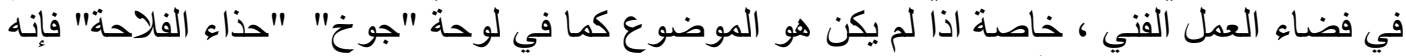

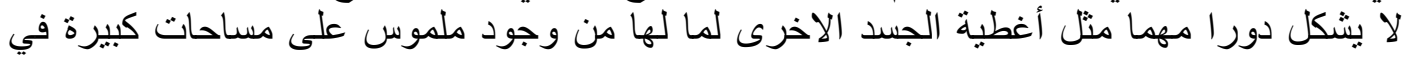
فضاء اللوحة يفرض جمالية لونية وشكلية ، وبهذه المواصفات تخرج من دورد دور لها الوظيفي لقدرتها 


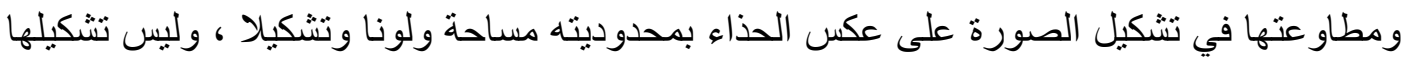

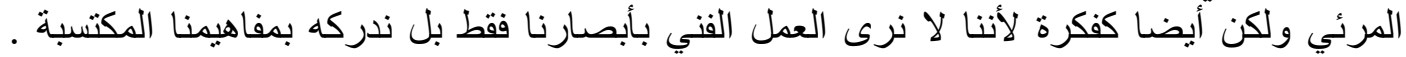

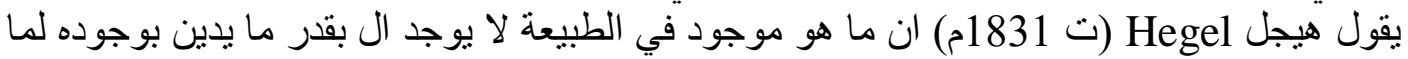

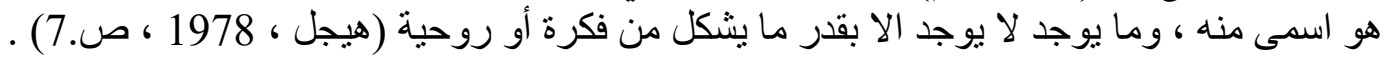

الناحية اللونية

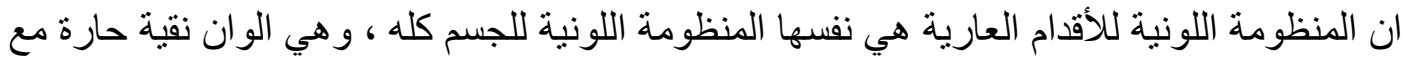

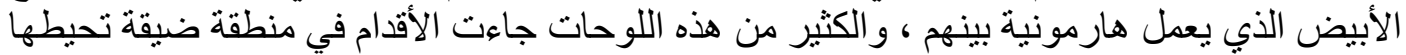

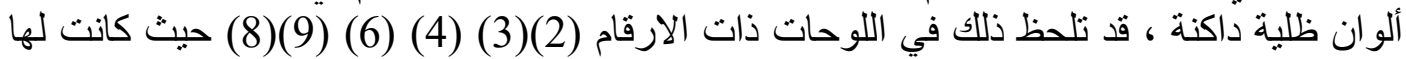

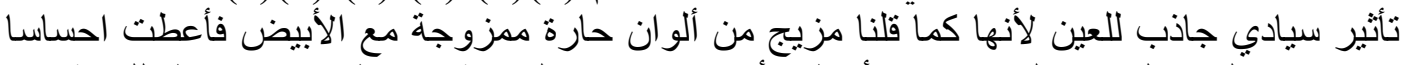

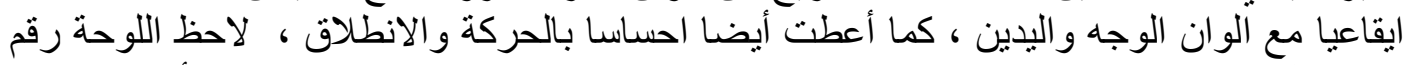

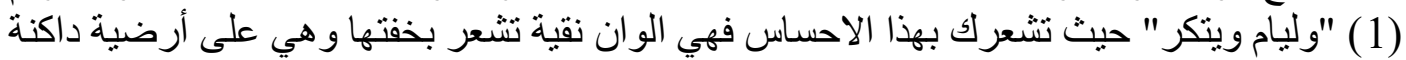

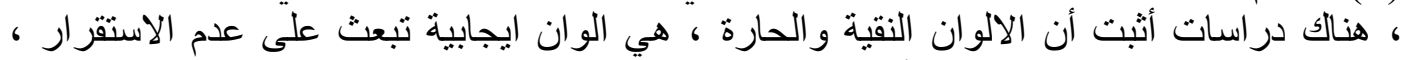

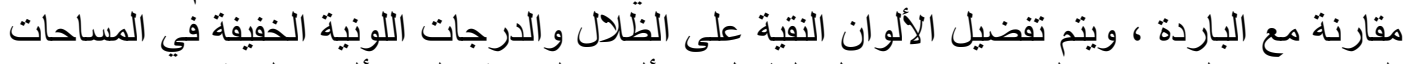

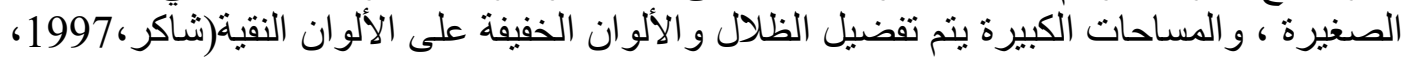

\section{الايقاع}

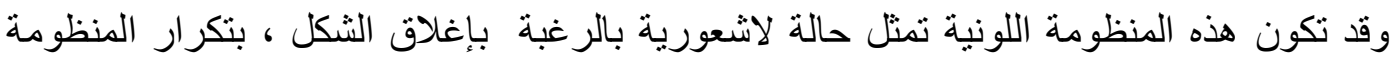

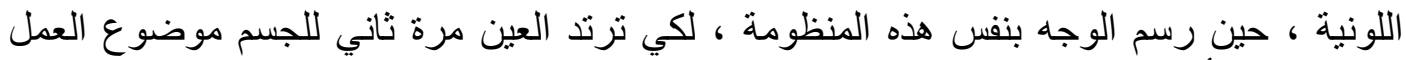

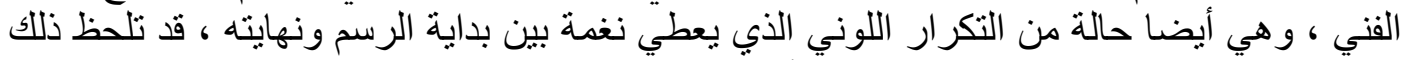

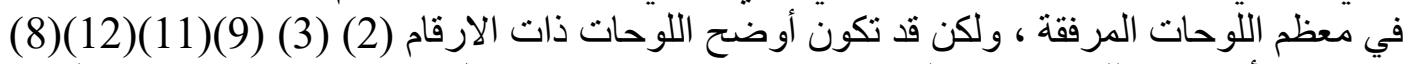

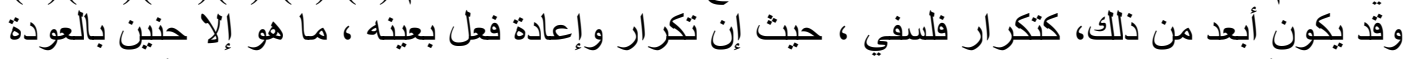

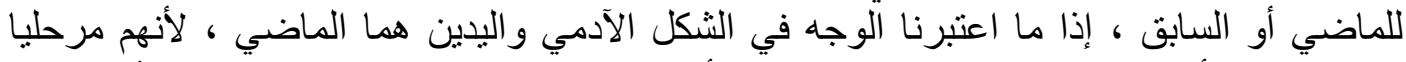

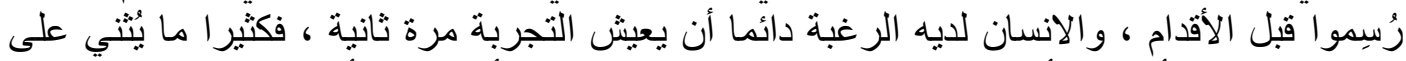

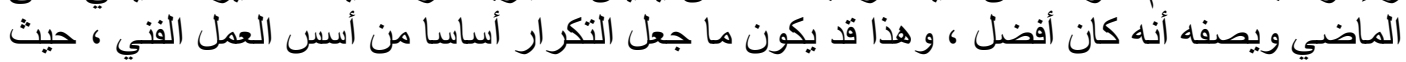

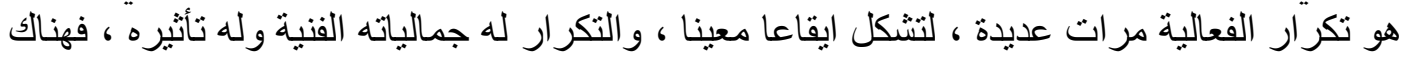

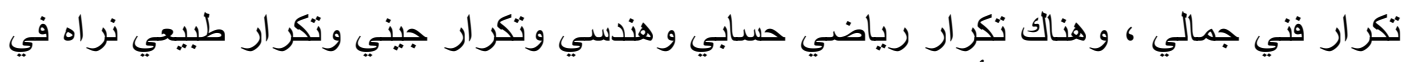

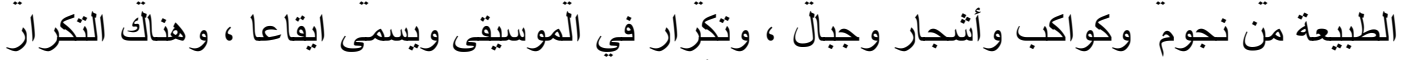

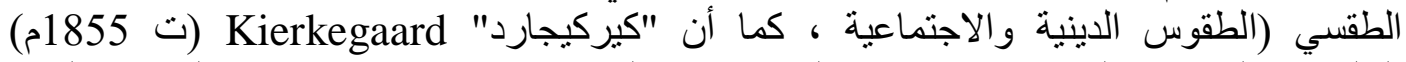

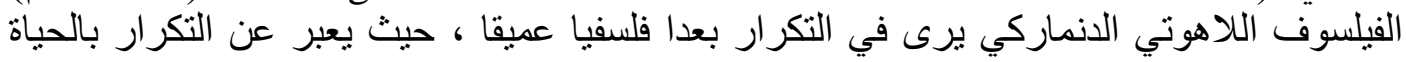

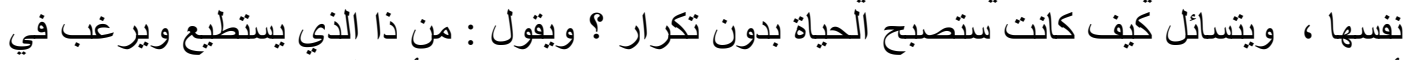

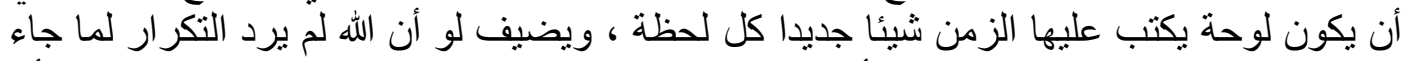

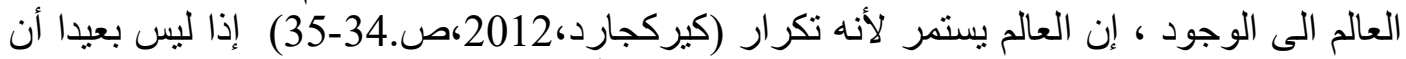

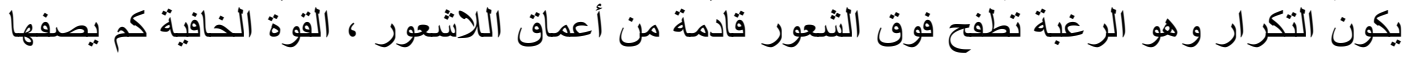
"يونج" .

الناحية العاطفية

قد تكون فكرة وجود روحية معينة في أي تمظهر وجودي تنطلق من كوننا أحياء نوقظ الحياة في

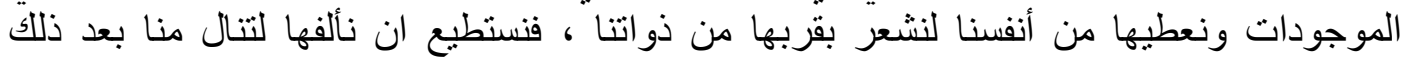




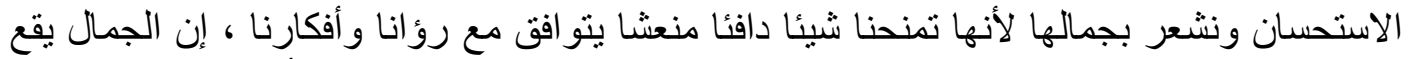

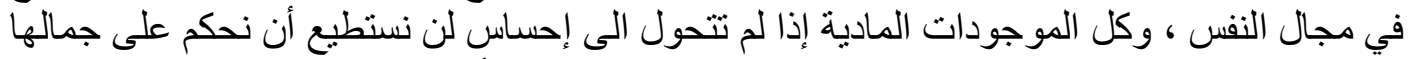

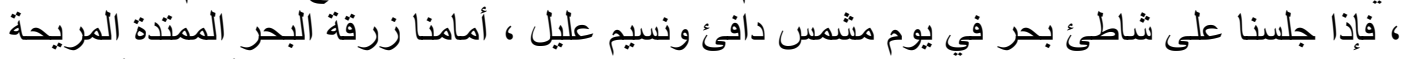

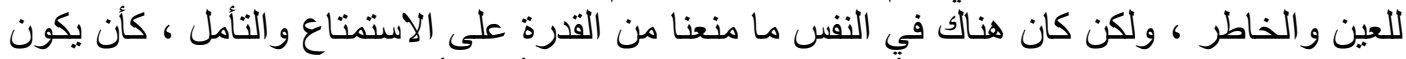

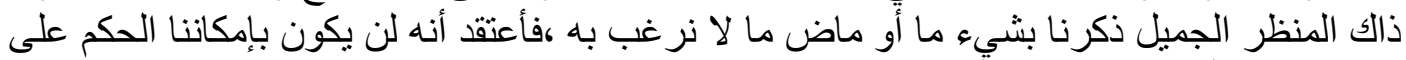

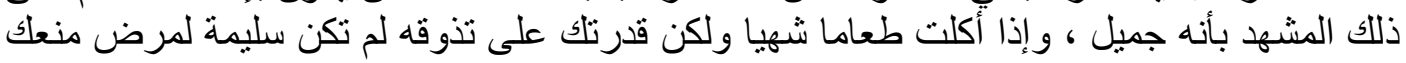

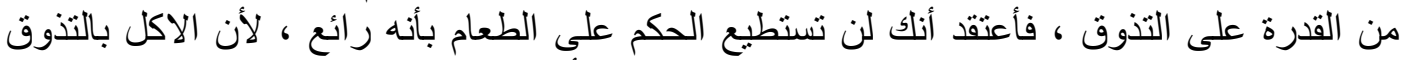

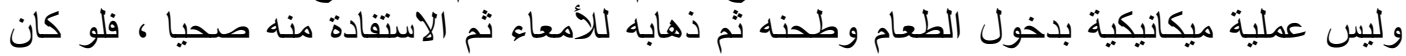

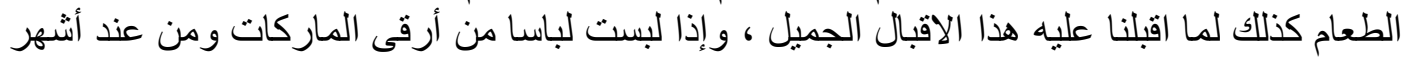

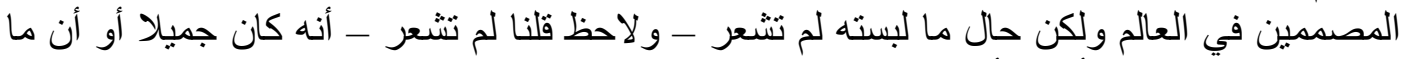

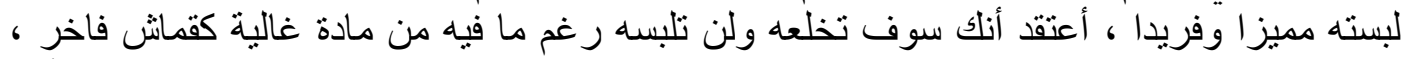

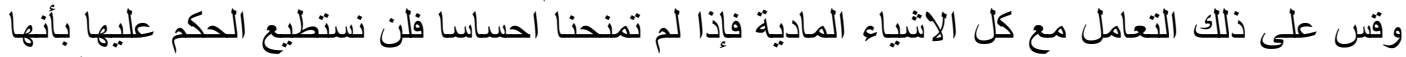

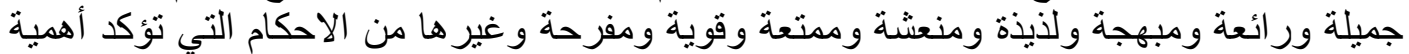

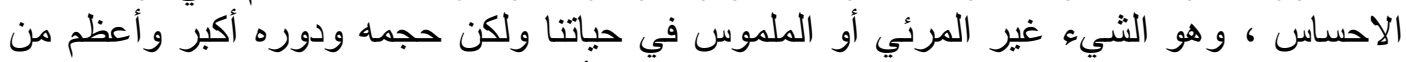

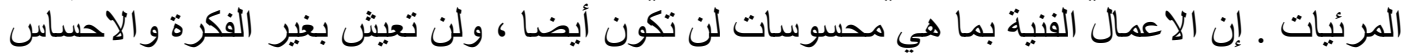

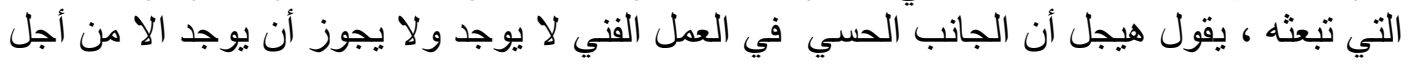

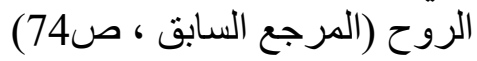




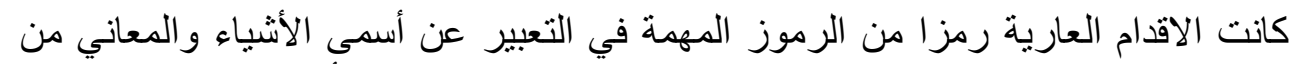

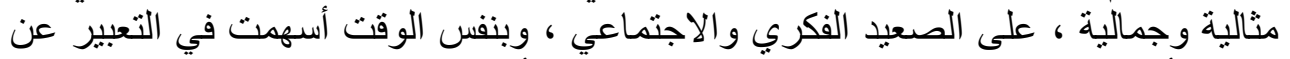

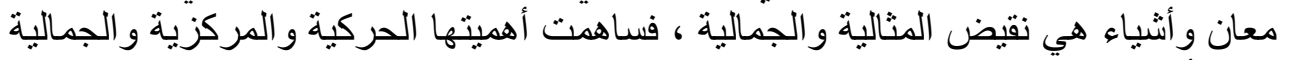

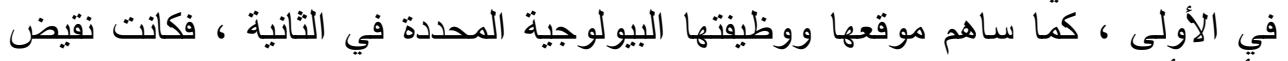
الأولى أبي نقيض المثالي و الجمالي.

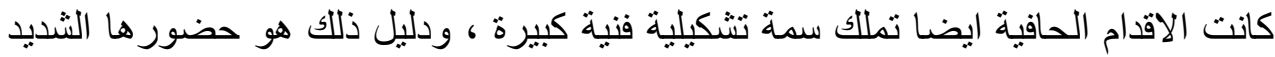

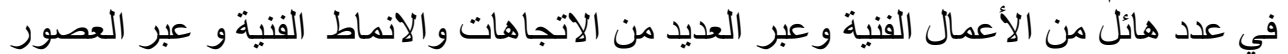

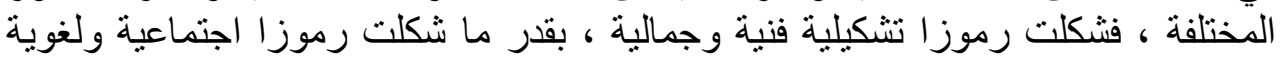
وفكرية ونفسية ورياضية .

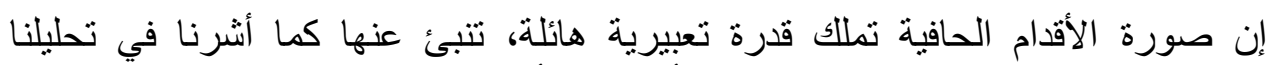

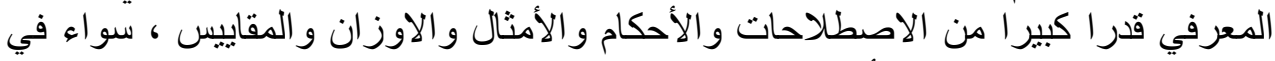

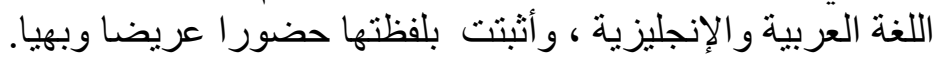

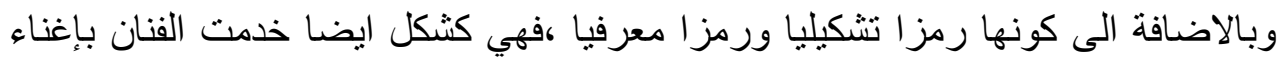

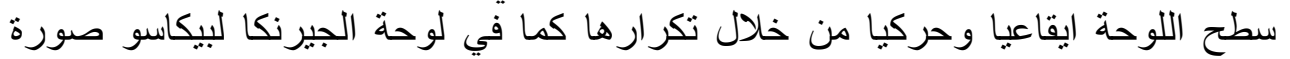

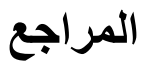

1-ابر اهيم ، زكريا - - الفن خبرة - القاهرة مكتبة مصر.

2-برجاوي ، عبد الرؤوف - 1981 - فصول في علم الجمال بيروت ـ دار الآفاق الجديدة .

3-برتليمي ، جان - 1970 - بحث في علع الجمال - القاهرة - دار النهضة .

4-بكر ، طارق - 2002- النقد الفنى المعاصر - الرياض- مكتبة الملك فهد الوطنية للنشر .

5-بونتي ،موريس - 1987 - المرئي و اللامرئي ـ الاسكندرية ـ دار الثروق الثقافية العامة.

6-توفيق،سعيد - 1992- الخبرة الجمالية - بيروت ـ المؤسسة الجامعية للنشر و التوزيع. 


$$
\text { 7-حسين ، محمد ـ ؟ - ديوان الأعثى - القاهرة - مكتبة الآداب بالجماميز. }
$$

8- ديورنت ، ول ـ ؟ - قصة الحضارة - القاهرة - الهيئة المصرية العامة للكتاب .

$$
\text { 9-ديوي ، جون - } 1963 \text { - الفن خبرة - القاهرة - دار النهضة . }
$$

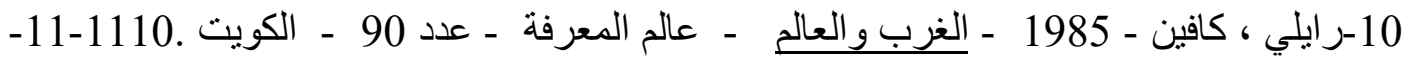
رياض ،عبد الفتاح- 1995 التكوين في الفنون الجميلة ـالقاهرة - دار النهضة. 12-زيدان ، جرجي - 2012 - شجرة الدر - القاهرة - مؤسسة هنداوي للتعليم والثقافة .

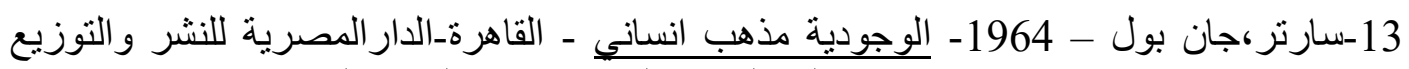

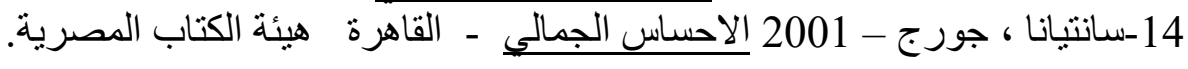
15-ستولنيتز ، جيروم - 1981 النقد الفني - القاهرة - الهيئة المصرية العامة للكتاب . 16-الصباغ ، رمضان - 2001 الفن و القيم الجمالية بين المثالية و المادية - الاسكندرية ـ دار المعارف لدنيا الطباعة . رمبان

17-عبد الحميد، شاكر - 1997 المفردات التثكيلية رموز ودلالاتـ مجلة نقوش- عدد -6 -6 - (ص. 6- 8 ، ص.575)القاهرة ـ الهيئة العامة لقصور الثقافة . 18-عبدالحميد، شاكر - 1978-العملية الابداعية_عالم المعرفة_عدد15-(ص.192) الكويت 19-عبدالحميد، شاكر - 1990- التفضيل الجمالي-عالم المعرفة_عدد 267 -(ص.9.9) الكويت 20-عمرو ، محمد - 2004 الرفلكسولوجي القاهرة الخيال للطباعة والنشر والتوزيع . 21-غاتثف، غيور غي-1990-الوعي و الفن_عالم المعرفة_عدد146_صر(12) صـ(113) 22-فارب ، بيتر - 1983 - بنو الانسان - عالم المعرفة - عدد- 67 - (ص.17 )-الكويت 23-فهيم ، حسين- 1986- فصول في تاريخ علم الانسان - عالم المعرفة -عدد 98 -ص (42)-

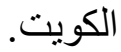

24-فنر ، أرنست - 1971 - ضرورة الفن - القاهرة ـ الهيئة المصرية العامة للكتاب . 25- كروتثة ، بندتو - 2009 - فلسفة الفن - بيروت - المركز الثقافي العربي . 26- كيركجاردد ، سورين - 2012 - التكر ار - القاهرة - مكتبة دار الكلمة للنشر و التوزيع . 27-ماركيوزز ، هيربرت - 1979 - البعد الجمالي - بيروت - دار الطليعة . 28- لاكوست ، جان - 2001 - فلسفة الفن - بيروت - عويدات للنشر و التوزيع . 29-هيجل ، فريدرك - 1996 - فلسفة الجمال عند هيجل - القاهرة - دار الثروق ز 30-هيجل، فريدريك - 1978 - مدخل الى علم الجمال- بيروت - دار الطليع للطباعة و النشر . 31-يونج ، كارل - 1997 - علم النفس التحليلي - اللاذقية ــ دار الحوار للنشر و التوزيع . 
1-Langer, Susan-1957-Problems of Art-New York-Scriber.

2-Mineke, Schipper-2006-Never Marry Woman with Big Foot.

3-Sparks, Joseph-1847-Book of the Feet History of Boots and Shoos

4-thaqafafsak.com

5-Almaany.com/page1-2

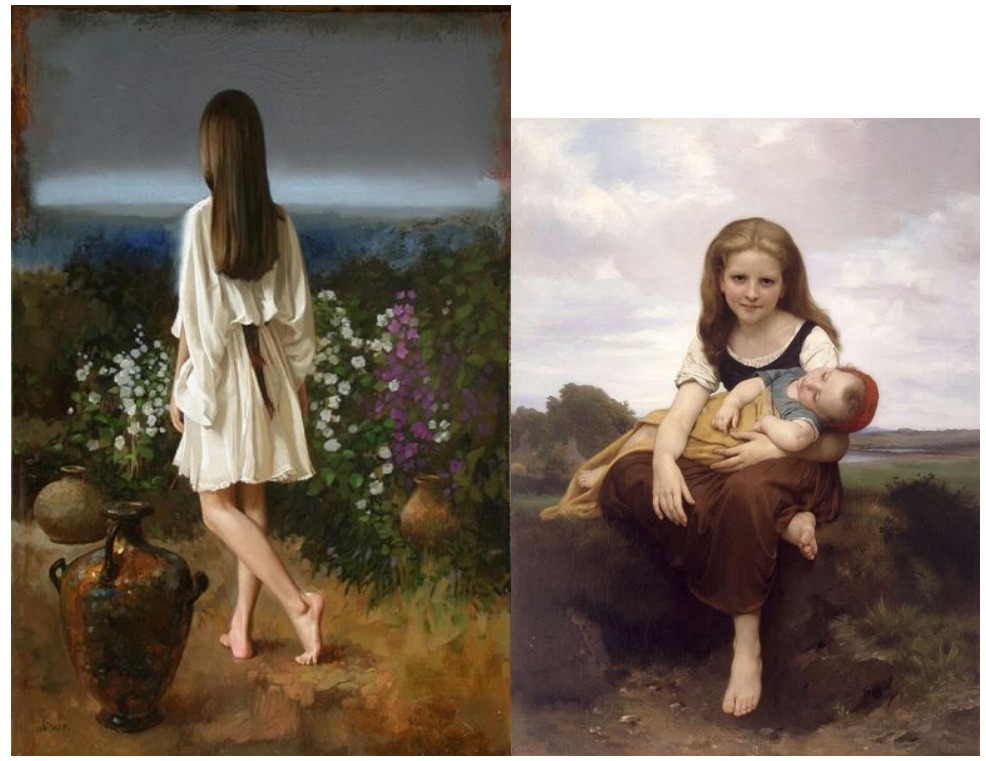

اللوحة(2) وليام بورجيو، القرن 19 و اقعي

اللوحة(1) وليام ويتكر، كلاسيكي،1840-1916 


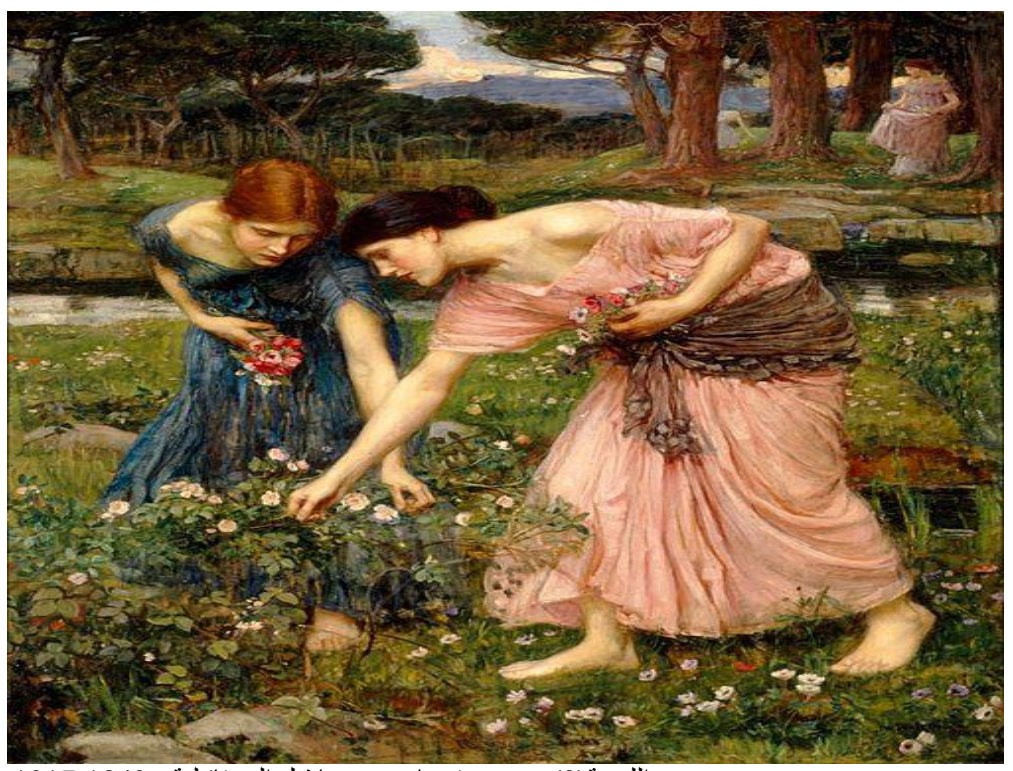

اللوحة(3) جون ووتر هاوس ، ما قبل الروفائيلية ، 1849-1917

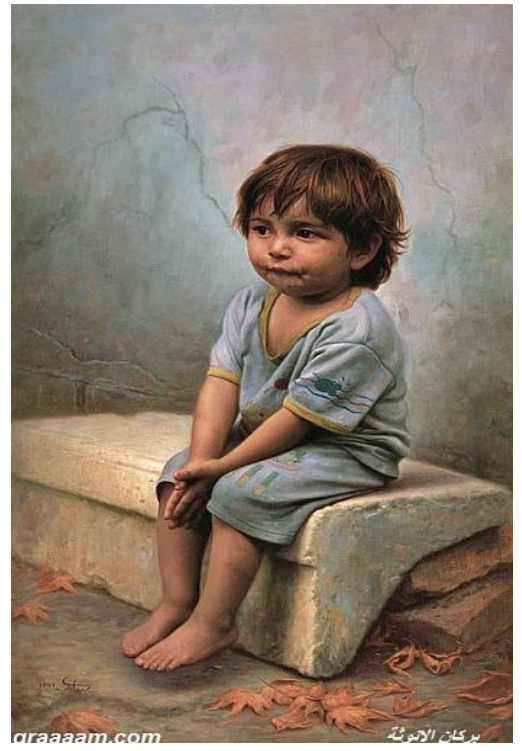

اللوحة(5) مجيد أرورو، اير اني معاصر ، ا واقعي

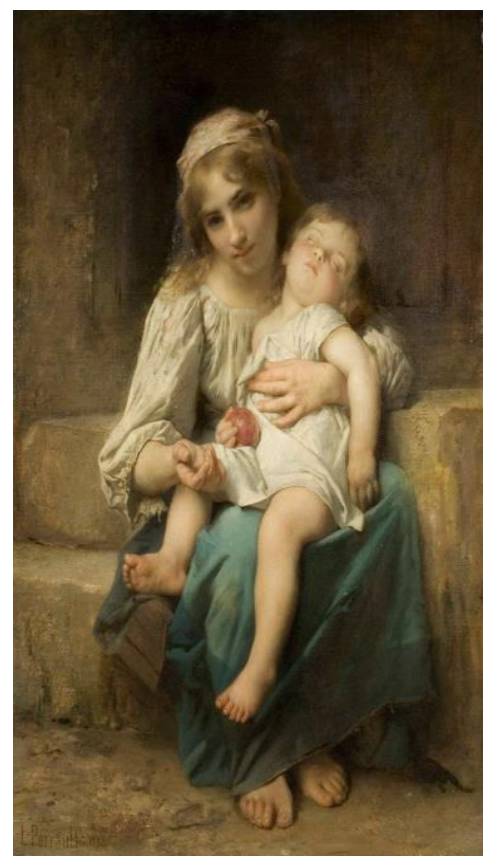

اللوحة(4) ليون جان باسيلي ، فرنسي 1832،- 1908 و اقعي 


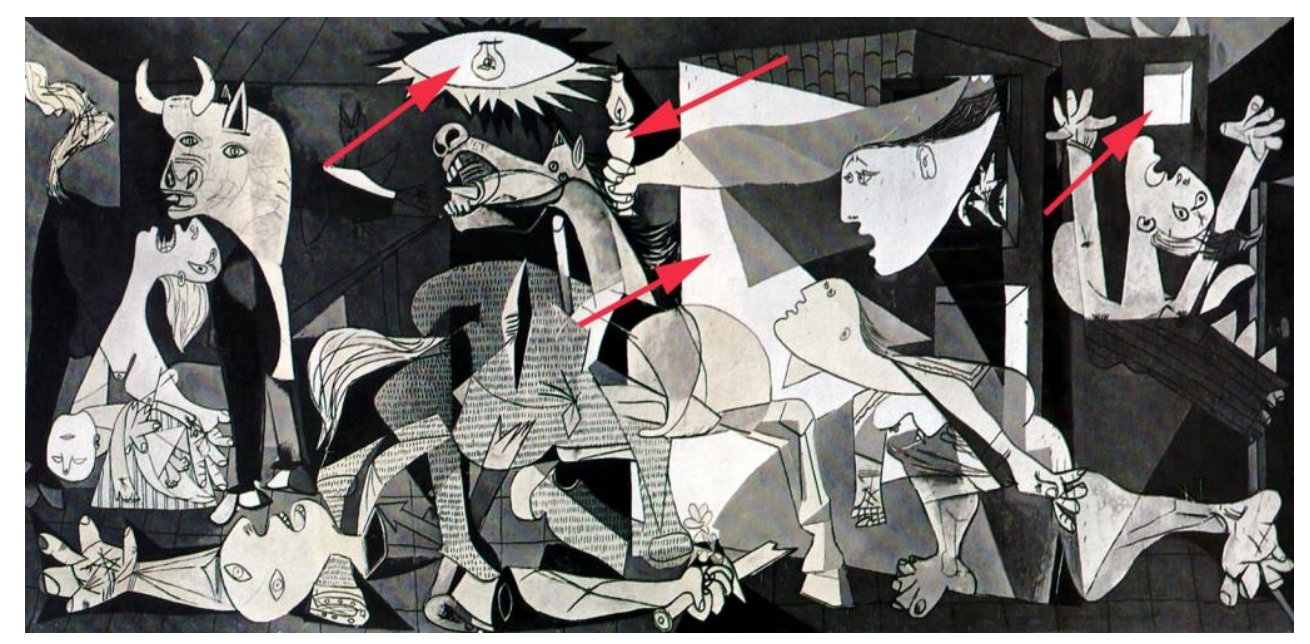

اللوحة رقم (6) بابلو بيكاسو ، فنان اسباني ، فن حديث .

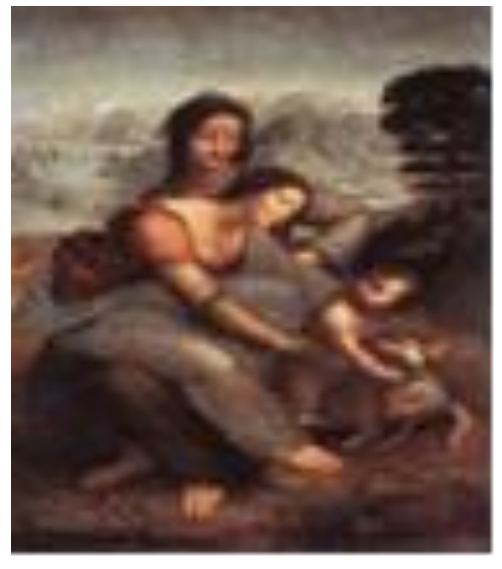

لوحة رقم (8) دافنشي كلاسيكي عصر النهضة

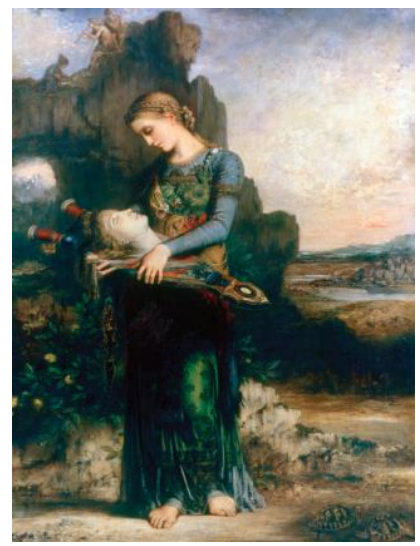

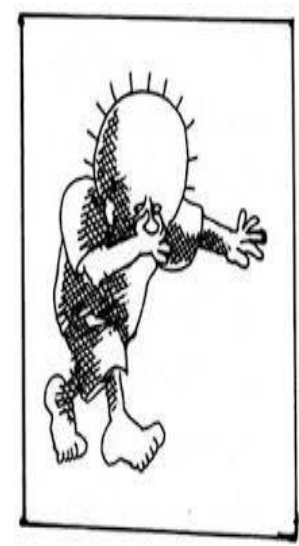

لوحة رقم(7) ناجي العلي

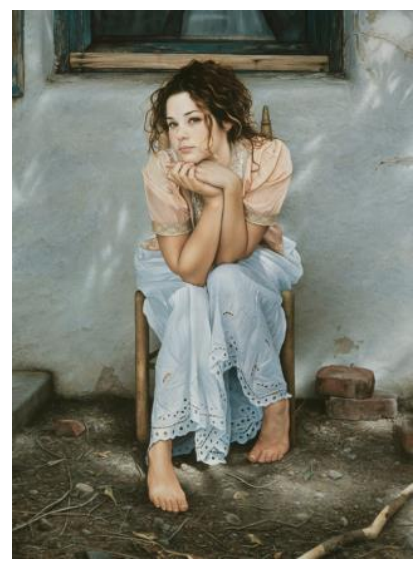




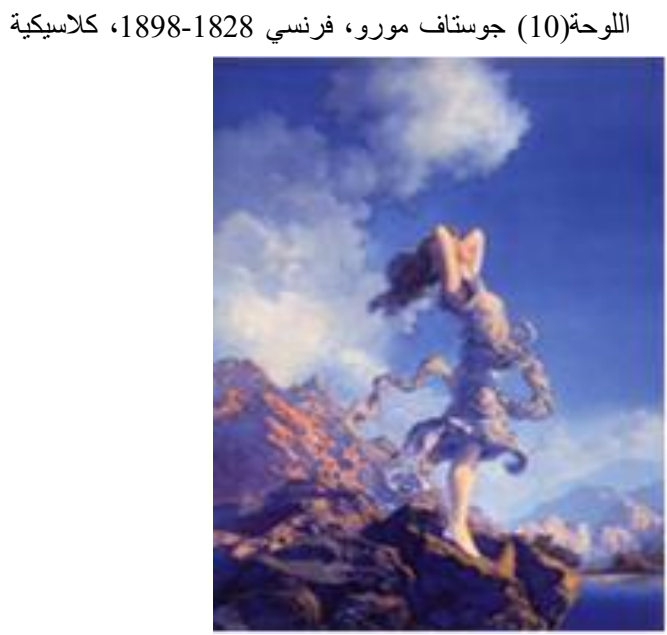

اللوحة (12) بيير أوغست كوت ، 183-1883 ، فرنسي

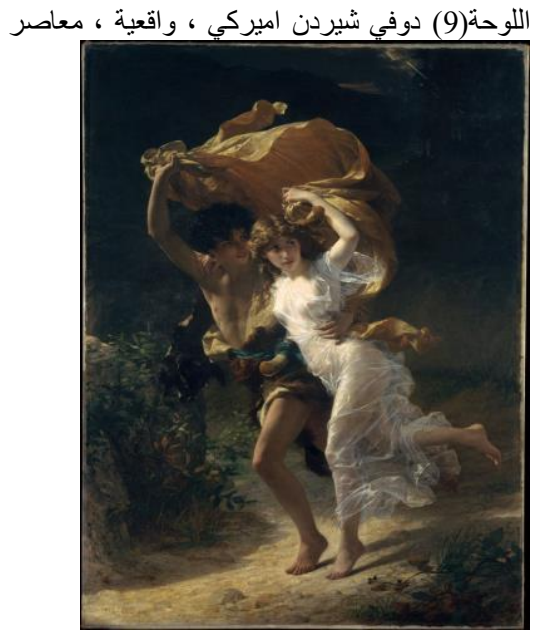

اللوحة (11) ماكسفيلا فن حديث 